Jurnal Akuntansi dan Manajemen

Vol.12, No.2, 2017, Hal. 85-114

\title{
ANALISIS KINERJA REKSA DANA SAHAM MENGGUNAKAN METODE SHARPE, TREYNOR DAN JENSEN DENGAN IHSG DAN LQ45 (REKSA DANA SAHAM YANG TERDAFTAR DI OJK TAHUN 2009-2013)
}

\author{
Ningsih Pratiwi 1), Randy Heriyanto \\ Jurusan Akuntansi, Politeknik Negeri Padang \\ Email: ningsih.pratiwi@gmail.com¹),heriyantorandy@gmail.com ${ }^{2)}$
}

\begin{abstract}
Abstact
Risk and Return are two things that must be considered in measuring portfolio performance, there are three parameters that have accommodated Risk and Return; Sharpe method, Treynor method, and Jensen method. These three performance measurements assume a relationship between portfolio returns, portfolio risks, and returns from several market indices. The measurement of stock portfolio performance can be facilitated by using a bench mark, which is IHSG and LQ 45 shares. The purpose of this study is to determine the performance of stock mutual funds against the CSPI and LQ 45. Penunlis conducted research on 29 conventional equity funds, which fulfilled the selected criteria purposive sampling. From the calculation results, it can be seen that only a number of mutual fund products are able to outperform the IHSG and LQ 45, but no one is able to survive consistently having the best performance during the 2009 to 2013 observation period. This is caused by changes in average returns and beta generated by mutual fund products.
\end{abstract}

Keywords: Equity Funds, IHSG, LQ 45, Sharpe Method, Treynor Method, and Jensen Method

\begin{abstract}
Abstact
Risk dan Return adalah dua hal yang harus diperhatikan dalam mengukur kinerja portofolio, terdapat tiga parameter yang telah mengakomodir Risk dan return yatu; Metode Sharpe, Metode Treynor, dan Metode Jensen. Ketiga pengukuran kinerja tersebut mengasumsikan adanya hubungan antara pengembalian (return) portofolio, resiko portofolio, dengan pengembalian dari beberapa indeks pasar. Pengukuran kinerja portofolio saham dapat dipermudah dengan menggunakan bench mark yaitu IHSG dan saham LQ 45. Tujuan penelitian ini untuk mengetahui kinerja dari reksa dana saham terhadap IHSG dan LQ 45. Penunlis melakukan penelitian pada 29 produk reksa dana saham konvensional, yang mememnuhi kriteria yang dipilih melalui purposive sampling. Dari hasil perhitungan dapat diketahui bahwa hanya beberapa produk reksa dana yang mampu outperform terhadap IHSG dan LQ 45, namun tidak ada yang mampu bertahan secara konsisten memiliki kinerja terbaik selama periode pengamatan 2009 sampai 2013. Hal ini disebabkan oleh perubahan average return dan beta yang dihasilkan oleh produk reksa dana.
\end{abstract}

Kata kunci : Reksa Dana Saham, IHSG, LQ 45, Metode Sharpe, Metode Treynor, dan Metode Jensen

\section{PENDAHULUAN}

Kemajuan pasar modal di suatu negara ditandai dengan besarnya kapitalisasi pasar, likuiditas pasar, perlindungan terhadap investor dan mekanisme pasar yang berjalan teratur. Semakin meningkatnya instrumen yang diperdagangkan di bursa dan semakin meningkatnya likuiditas pasar maka para investor internasional akan tertarik untuk masuk ke dalam pasar modal Indonesia. Selain itu, pasar modal yang maju akan menghambat larinya dana investor dalam negeri ke pasar luar negeri.

Pasar modal Indonesia telah mencatat perkembangan yang cukup menggembirakan. Hal ini terbukti meningkatnya jumlah investasi yang tercatat di pasar modal. Bagi dunia usaha, pasar modal memberikan alternatif pembiayaan yang 
menarik melalui kemungkinan penggalangan dana. Di sisi lain, bagi para pemilik dana, pasar modal memberikan berbagai pilihan investasi mulai dari yang relatif tinggi resikonya sampai pada pilihan berisiko rendah. Alternatif yang semula terbatas pada saham dan obligasi saja, kini semakin beragam. Salah satu instrumen yang akhir-akhir ini populer di Indonesia adalah reksadana.

Dalam waktu singkat, jumlah reksadana yang ditawarkan kepada para pemodal telah menunjukkan banyak perubahan. Sifat instrumennya yang tidak terlalu rumit, membuat reksadana cepat populer. Dibandingkan dengan pilihan untuk berinvestasi langsung dalam bentuk saham reksa dana lebih sederhana sifatnya dan dibandingkan dengan bunga deposito yang sekarang kurang diminati karena bunganya tidak lagi mengundang orang untuk berinvestasi di bank. Reksa dana adalah wadah sekaligus wahana investasi bagimasyarakat yang ingin berinvestasi pada instrumen investasi. Namun dalam setiap investasi selalu ada risiko yang perlu diketahui terlebih dahulu sebelum memiliki suatu produk investasi. Karena tidak ada sesuatu yang pasti di dunia ini kecuali ketidakpastian itu sendiri.

Reksa dana mulai diperdagangkan di Indonesia sejak tahun 1995 dengan diterbitkan Undang-undang No. 8 tahun 1995 tentang pasar modal. Adanya kemudahan investasi membuat perkembangan reksa dana semakin pesat sampai tahun 1997. Pada tahun 2014 sesuai dengan data OJK (Otoritas Jasa Keuangan) jumlah dana kelolaan seluruh jenis reksa dana berjumlah Rp 220,13 triliun dan $42 \%$ atau Rp 92,57 triliun dari jumlah tersebut merupakan total dana kelolaan reksa dana saham dari 77 manager investasi. Sedangkan untuk total Nilai Aset Bersih seluruh reksa dana berjumlah sekitar RP 218,435 triliun per November 2014.

Dewi dan Ferdian (2006) mengevaluasi reksadana syariah di Indonesia dan Malaysia. Hasil penelitian menunjukkan bahwa hasil pengukuran kinerja reksa dana syariah di Indonesia menggunakan metode Sharpe, Treynor dan Jensen menghasilkan hasil yang sama dalam artian nilai indeks yang positif atau negatif.

Sulistyorini (2009) penelitian ini mengevaluasi kinerja portofolio saham menggunakan metode Sharpe, Treynor dan Jensen, namun sebelum melakukan perbandingan dilakukan terlebih dahulu transformasi nilai indeks masing-masing metode menjadi Z-score (Standardized). Hasil uji menunjukkan bahwa tidak ada perbedaan signifikan dalam mengukur kinerja portofolio menggunakan metode Sharpe, Treynor dan Jensen.

Susiana dan Kaudin (2009) meneliti reksa dana saham di Indonesia selama periode 2006. Metode pengukuran menggunakan metode Sharpe, Treynor, Jensen dan Henrickson and Merton. Hasil menunjukkan bila menggunakan metode pengukuran kinerja yang berbeda maka hasilnya akan berbeda pula pada masing-masing metode.

Prajapati dan Patel (2012) meneliti reksa dana di India menggunakan metode rasio Treynor, rasio Sharpe, rasio Jensen dan Fama Measure selama periode Januari 2007 hingga Desember 2011. Hasilnya menunjukkan banyak reksa dana yang memiliki return positif. Metode Treynor menunjukkan hasil yang lebih baik dibanding metode Sharpe dan Jensen.

Hasil penelitian terdahulu tentang pengukuran kinerja reksa dana menggunakan metode Sharpe, Treynor dan Jensen hanya terdapat beberapa kinerja reksa dana yang memiliki kinerja di atas kinerja pasar namun tidak terdapat yang konsisten dalam beberapa periode (phenomena gap) dan berdasarkan data yang diperoleh dari OJK mengenai meningkatnya investasi di pasar modal khususnya pada instrumen investasi reksa dana, maka phenomena gap yang terjadi bahwa reksa dana 
tidak selalu memiliki kinerja lebih baik dibandingkan kinerja pasar menjadi rumusan masalah pada penelitian ini..

Dengan demikian perlu adanya metode yang dapat memberikan hasil mengenai pengukuran kinerja reksa dana yang benar dan akurat. Oleh karena itu pada penelitian ini digunakan metode Sharpe, Treynor dan Jensen. Informasi mengenai hasil pengukuran kinerja reksa dana sangat penting bagi investor maupun manajer investasi, karena hasil dari penelitian ini akan memberi gambaran akan metode yang dapat memberikan hasil yang sama. Mengingat pentingnya informasi mengenai kinerja reksa dana maka dalam penelitian ini dipilih judul : "Analisis Kinerja ReksaDana Saham Menggunakan Metode Sharpe, Treynor Dan Jensen Dengan IHSG dan LQ45 (Reksa Dana Saham Yang Terdaftar di OJK Tahun 2009-2013) ".

\section{TINJAUAN PUSTAKA DAN PERUMUSAN HIPOTESIS}

\section{Investasi}

Investasi adalah sejumlah dana yang digunakan dengan harapan dapat memberikan keuntungan tertentu di masa yang akan datang. Investasi melibatkan pengeluaran dana investor pada waktu sekarang untuk mendapatkan pengembalian yang lebih besar di masa yang akan datang, walaupun pengembalian dari suatu investasi belum tentu berupa keuntungan. Dengan kata lain tujuan penanaman dana yang dilakukan investor adalah untuk mendapatkan keuntungan di masa yang akan datang.

\section{Reksa Dana}

Reksa dana adalah wadah yang dipergunakan untuk menghimpun dana dari masyarakat pemodal untuk selanjutnya diinvestasikan dalam portofolio efek oleh manajer investasi. Pemodal yang menempatkan dananya pada reksa dana akan mendapatkan return investasi berupa deviden, bunga, atau capital gain sesuai dengan jenis reksa dana yang mereka pilih. Reksa dana merupakan investasi yang bersifat fleksibel, karena investasi ini dapat ditempatkan pada berbagai instrumen efek, baik di pasar uang maupun pasar modal sesuai dengan tujuan dan kebutuhan investor dalam berinvestasi. Jadi semakin bervariasi bentuk suatu investasi semakin kecil risiko yang dihadapi. Variasi investasi pada instrumen efek ini dinamakan diversifikasi portofolio.

\section{Bentuk Reksa Dana}

Berdasarkan Undang-undang Pasar Modal Nomor 8 Tahun 1995 pasal 18, ayat (1), bentuk hukum reksa dana di Indonesia ada dua, yakni:

1) Reksa Dana Perusahaan (investment companies)

Reksadana perusahaan (investment companies) adalah reksa dana berbentuk suatu perusahaan yang mempunyai kegiatan usaha mengelola portofolio efek. Perseroan yang telah mendapat ijin usaha dari Bapepam. Investor yang tertarik berinvestasi pada reksa dana ini dapat membeli saham yang dikeluarkan perusahaan tersebut. Reksa dana perusahaan dapat bersifat terbuka atau tertutup.

2) Reksa Dana Kontrak Investasi Kolektif (unit investment trust)

Reksa dana kontrak investasi kolektif (unit investment trust) adalah reksa dana yang dibentuk berdasarkan suatu Kontrak Investasi Kolektif (KIK) antara manajer investasi dan bank kustodian. Investor yang tertarik berinvestasi pada reksa dana tersebut dapat membeli unit penyertaan yang dikeluarkan reksa dana tersebut. Reksadana kontrak investasi kolektif 
hanya bersifat terbuka.Pengelolaan reksa dana yang dilakukan oleh manajer investasi baik dalam bentuk investment companies maupun unit investment trust selalu berdasarkan kontrak. Untuk reksa dana berbentuk investment companies kontrak pengelolaan dibuat oleh direksi dengan manajer investasi. Sedangkan pengelolaan unitinvestment trust dibuat antara manajer investasi dan bank kustodian.

\section{Sifat Reksa Dana}

Dilihat dari segi sifatnya atau cara penerbitan dan perdagangan sahamnya menurut Undang-undang Pasar Modal Nomor 8 Tahun 1995 pasal 18, ayat (1) reksa dana dapat dibedakan menjadi dua yaitu :

1. Reksa Dana Tertutup (close end funds)

Reksa dana yang menerbitkan saham atau unit penyertaan dan menjualnya kepada investor namun tidak memiliki kewajiban untuk membeli saham atau unit penyertaan yang telah dijualnya. Investor hanya dapat menarik investasinya dengan cara menjual atau mengalihkan saham atau unit penyertaan yang dimilikinya kepada investor lain yang berminat.

2. Reksa Dana Terbuka (open end funds)

Reksa dana yang menerbitkan sahamatau unit penyertaan dan menjualnya kepada investor dan memiliki kewajiban untuk membeli kembali saham atau unit penyertaan yang telah dijualnya. Manajer investasi reksa dana terbuka berbentuk investment companies dan unit investment trust wajib menghitung nilai pasar wajar dari efek dalam portofolio setiap hari bursa berdasarkan ketentuan yang ditetapkan oleh Bapepam. Nilai saham reksa dana terbuka berbentuk investment companies dan unit investment trustditentukan berdasarkan nilai aktiva bersih, nilai aktiva bersih wajib dihitung dan diumumkan untuk informasi publik. Semua kekayaan reksa dana wajib disimpan pada bank kustodian.

\section{Jenis Reksa Dana}

Berikut ini adalah macam-macam jenis atau produk reksa dana yang ada pada saat ini berdasarkan Undang-undang Pasar Modal Nomor 8 Tahun 1995 pasal 18, yaitu:

1. Reksa Dana Konvensional (Biasa)

Reksa dana konvensional (biasa) adalah reksa dana yang dapat dibeli atau dijual kembali oleh investor setiap saat tergantung tujuan investasi, jangka waktu dan profil risiko investor

2. Reksa Dana Terstruktur

Reksa dana terstruktur adalah reksa dana yang hanya dapat dibeli atau dijual kembali oleh investor pada saat tertentu saja yang ditentukan oleh manajer investasi

\section{Risiko Investasi Reksa Dana}

Berikut ini adalah risiko yang akan dihadapi oleh investor yang akan berinvestasidi reksa dana:

a. Resiko Berkurangnya Nilai Unit Penyertaan.

b. Resiko Likuiditas.

c. Resiko Pertanggungan atas Kekayaan Reksa Dana.

d. Resiko Perubahan Politik Ekonomi.

e. Resiko Penurunan Suku Bunga 
f. Resiko Pertukaran Mata Uang.

Manfaat Investasi Reksa Dana

Reksa dana memiliki beberapa manfaat yang menjadikannya sebagai salah satu alternatif investasi yang menarik antara lain:
a. Dikelola oleh manajemen profesional
b. Diversifikasi investasi
c. Transparansi informasi
d. Likuiditas yang tinggi
e. Biaya rendah

\section{Pihak-pihak Penunjang Reksa Dana}

Adapun pihak-pihak yang menunjang dalam kegiatan reksa dana yangdinyatakan dalam Undang-Undang Pasar Modal No.8 tahun 1995 pasal 18 antara lain :
a. Kontrak Investasi Kolektif (KIK)
b. Manajer Investasi
c. Bank Kustodian
d. Auditor
e. Konsultan Hukum atau Notaris
f. Agen Penjual

\section{Aspek Yang Mempengaruhi Tingkat Pengembalian Reksa Dana Saham}

Reksadana merupakan salah satu pilihan untuk berinvestasi dibanding investasi dari instrumen lain. Reksadana mampu memberikan tingkat pengembalian yang lebih tinggi, tetapi semakin tinggi tingkat pengembaliannya semakin tinggi pula resikonya. Pada dasarnya reksadana merupakan kumpulan dana yang diinvestasikan kepada portofolio efek dan dikelola oleh manajer investasi. Secara umum berdasarkan konsep tersebut ada beberapa aspek yang menyebabkan reksadana beresiko (Sulistyorini, 2009). Aspek-aspek tersebut adalah:

1. Dana yang diperoleh dari masyarakat diinvestasikan kepada portofolio efek Portofolio efek yaitu kumpulan efek yang memberikan hasil kepada pemiliknya. Saham mempunyai jangka waktu yang paling panjang dari semua instrumen investasi yang ada dan resiko paling tinggi. Harga saham sangat fluktuatif tergantung prospek perusahaan yang dikenal dengan fundamental perusahaan dan juga penawaran (supply) dan permintaan (demand) saham tersebut. Harga yang sangat fluktuatif ini juga menyatakan bahwa saham sangat berisiko dan tingkat pengembaliannya tidak dapat ditentukan.

2. Portofolio efek tersebut sangat bervariasi sehingga masing-masing instrumen mempunyai tingkat pengembalian yang berbeda-beda. Tingkat pengembalian dari instrumen investasi dari portofolio efek tersebut dapat berubah-rubah setiap waktu dan mengakibatkan tidak dapat ditentukan tingkat pengembalian dari portofolio secara keseluruhan. Akibatnya, manajer investasi tidak dapat menentukan atau menjamin tingkat pengembalian portofolionya. Bila tingkat pengembalian tersebut tidak dapat ditentukan maka tidak ada kewajiban bagi manajer investasi untuk menentukan angka tertentu sebagai tingkat pengembalian portofolionya.

3. Keahlian manajer investasi 
Keahlian manajer investasi mengelola portofolio juga merupakan salah satu timbulnya risiko dari portofolio dan juga kepastian tingkat pengembalian. Setiap manajer investasi mempunyai alokasi aset (asset allocation), kemampuan pemilihan instrumen investasi (stock selection) dan kemampuan menilai waktu jual beli di pasar (market timing) yang berbeda-beda. Semua keahlian ini sangat menentukan tingkat pengembalian portofolio yang dikelola oleh manajer investasi. Bila keahlian ini tidak maksimal dipergunakan maka risiko portofolio dapat menjadi lebih tinggi dan tingkat pengembalian juga semakin tidak pasti.

\section{Nilai Aktiva Bersih Reksa Dana}

Nilai aktiva bersih merupakan jumlah aktiva setelah dikurangi kewajibankewajiban yang ada. Sedangkan NAB per unit penyertaan merupakan jumlah NAB dibagi dengan jumlah unit penyertaan yang beredar. Nilai NAB sangat bergantung dengan kinerja asset yang merupakan portofolio reksa dana. Jika harga pasar aset-aset suatu reksa dana mengalami kenaikan dan demikian pula sebaliknya.

$$
\mathrm{NAB}=\frac{\text { (Jumlah Aset }- \text { Total Kewajiban) }}{\text { Jumlah Unit Penyertaan }}
$$

NAB per unit dihitung setiap hari oleh bank kustodian setelah mendapat data dari manajer investasi dan nilai tersebutlah yang kemudian setiap hari dapat dilihat pada keesokan harinya di media massa setiap hari kerja. Berdasarkan informasi NAB yang transparan kepada umum, setiap orang dapat menghitung tingkat pengembalian reksa dana selama satu periode pengamatan. Dengan rumus:

Keterangan:

$$
\text { Kinerja } \mathrm{RD}_{\mathrm{RD}}=\frac{\mathrm{NAK}-\mathrm{NAW}}{\mathrm{NAW}}
$$

Kinerja RD : Kinerja Reksa Dana

NAK : Nilai Aktiva Bersih/ unit akhir bulan ini

NAW : Nilai Aktiva Bersih/ unit akhir bulan sebelumnya

\section{Biaya Reksa Dana}

Biaya merupakan harga yang harus dibayar untuk mendapatkan sesuatu. Dalam konteks reksa dana maka biaya adalah sejumlah harga yang harus dikeluarkan agar dapat berinvestasi di reksa dana. Menurut Manurung (2008) dalam Sulistyorini (2009) biaya dapat mengurangi tingkat pengembalian yang diterima investor. Biaya diharapkan sangat kecil agar hasil yang diperoleh cukup besar. Dengan biaya yang kecil maka diharapkan tingkat pengembalian yang diterima menjadi lebih besar.

Adapun biaya-biaya tersebut dapat dikelompokkan kepada tiga biaya (Manurung 2008) dalam (Sulistyorini, 2009) yaitu:

a) Biaya ketika investor membeli reksa dana

b) Biaya yang dikeluarkan reksa dana itu sendiri sebagai badan hukum

c) Biaya ketika investor keluar dari reksa dana

Biaya pertama yaitu biaya yang dikeluarkan ketika investor membeli reksa dana dikenal dengan biaya pembelian atau biaya penjualan (subscriptioncost). Biaya ini sangat bervariasi tidak ada yang sampai dua persen. Selanjutnya, biaya-biaya yang dikeluarkan oleh reksa dana itu sendiri. Yaitu biaya untuk bank kustodian dan biaya untuk manajer investasi, serta biaya lain yang berkaitan dengan reksa dana. Biaya ketiga yang dibayarkan oleh investor yaitu ketika investor menarik atau menjual kembali unit reksa dananya kepada manajer investasi. Biaya ini dikenal dengan biaya 
penjualan kembali (redemption fee). Besarnya biaya ini bervariasi dari nol persen sampai dengan dua persen.

\section{Benchmark}

Pengukuran kinerja reksa dana tidak dapat dilakukan secara individu saja, melainkan harus dibandingkan dengan kinerja portofolio sejenis agar diketahui apakah kinerjanya lebih baik atau lebih buruk dari kinerja pasar. Oleh karena itu pembanding (benchmark) suatu kinerja portofolio sangat penting apabila ingin melakukan pengukuran kinerja reksa dana. Menurut Rahardi, 2013 (dikutip dari Sharpe, et al 1999) benchmark dalam evaluasi kinerja portofolio harus mewakili kebijakan investasi dari portofolio, serta tidak berlawanan dengan tujuan investasi investor.

Benchmark yang sesuai dengan masing-masing reksa dana adalah sebagai berikut:

a) Reksa dana saham: Indeks Harga Saham Gabungan (IHSG)

b) Reksa dana pendapatan tetap: Suku bunga deposito

c) Reksa dana pasar uang: Indeks obligasi

d) Reksa dana campuran: Rata-rata suku bunga deposito dan IHSG

\section{Return Benchmark}

Return benchmark merupakan return atau kinerja portofolio pembanding reksa dana. Return portofolio pembanding disebut juga dengan return pasar. Portofolio pembanding (benchmark) yang dimaksud harus sesuai dengan jenis reksa dana yang dibandingkan. Pengukuran return pasar digunakan untuk membandingkan dengan return reksa dana saham, reksa dana pendapatan tetap dan reksa dana campuran berdasarkan metode pengukuran yang digunakan, dimasukkan pada variable pasar sebagai pembanding (benchmark) sesuai dengan jenis masing-masing reksa dana, dalam (Pratomo dan Ubaidillah, 2002). Masing-masing return pasar tersebut adalah sebagai berikut:

a) Return IHSG

Return IHSG adalah nilai return pasar saham sub periode tertentu yang diperoleh dari nilai tukar Indeks Harga Saham Gabungan akhir bulan dikurangi dengan nilai akhir bulan sebelumnya Indeks Harga Saham Gabungan kemudian hasilnya dibagi dengan nilai akhir bulan sebelumnya Indeks Harga Saham Gabungan. Return IHSG kerap digunakan sebagai benchmark pada reksa dana saham. Alasan pemakaian IHSG adalah IHSG merupakan portofolio saham yang menggambarkan kondisi pasar secara umum sehingga pada reksa dana saham yang mayoritas (minimal 80\%) dananya diinvestasikan pada instrumen saham, maka IHSG sangat sesuai digunakan. Dirumuskan:

Keterangan:

$$
\mathrm{K}_{\mathrm{IHSG}}=\frac{\mathrm{IHSG}_{\mathrm{t}}-\mathrm{IHSG}_{\mathrm{t}-1}}{\mathrm{IHSG}_{\mathrm{t}-1}}
$$

K IHSG

: Return IHSG

IHSG $\mathrm{t} \quad$ : Return Pasar IHSG periode ini

IHSG $\mathrm{t}-1 \quad$ : Return pasar IHSG periode sebelumnya

b) Return LQ45

Return LQ45 adalah nilai return pasar saham sub periode tertentu yang diperoleh dari nilai LQ45 akhir bulan dikurangi dengan nilai akhir bulan sebelumnya LQ45 kemudian hasilnya dibagi dengan nilai akhir bulan 
sebelumnya LQ45. LQ45 merupakan saham likuid kapitalisasi pasar yang tinggi, memiliki frekuensi perdagangan tinggi, memiliki prospek pertumbuhan serta kondisi keuangan yang cukup baik, tidak fluktuatif dan secara obyektif telah diseleksi oleh BEI dan merupakan saham yang aman dimiliki karena fundamental kinerja saham tersebut bagus, sehingga dari sisi risiko kelompok saham LQ45 memiliki resiko terendah dibandingkan saham-saham lain. Fluktuatif harga pada kelompok saham LQ45 cenderung smooth menjadikan return dari capital gain tidak setinggi pada kelompok saham yang mengalami fluktuasi harga siginifikan.

Dirumuskan:

Keterangan:

$$
\mathrm{K}_{\mathrm{LQ45}}=\frac{\mathrm{K}_{\mathrm{LQ} 45 \mathrm{t}}-\mathrm{K}_{\mathrm{LQ} 45 \mathrm{t}-1}}{\mathrm{~K}_{\mathrm{LQ} 45 \mathrm{t}-1}}
$$

$\begin{array}{ll}\text { K LQ45 } & \text { : Return LQ45 } \\ \text { LQ45 t } & : \text { Return pasar LQ45 periode ini } \\ \text { LQ45 t-1 } & \text { : Return pasar LQ45 periode sebelumnya }\end{array}$

\section{Risk Free Rate}

Investasi yang bebas risiko (risk free rate) secara teori ada dua faktor utama pada investasi ini yaitu return tetap dan risiko tidak ada atau tidak memiliki kemungkinan default atau gagal bayar

$$
\operatorname{Kinerja}_{R F}=\frac{R_{F 1 t}+R_{F 2 t}+R_{F n t}}{n}
$$

Keterangan:

$$
\begin{array}{ll}
\text { Kinerja } R F & \text { : Kinerja investasi bebas risiko } \\
\text { RF1t, RF2t, RFnt } & \text { : Suku bunga SBI periode t } \\
n & \text { : Jumlah periode pengamatan }
\end{array}
$$

\section{Pengukuran Kinerja Reksa Dana}

Pengukuran kinerja sangat penting dilakukan baik bagi manajer investasi maupun investor. Hal ini diperlukan untuk mengevaluasi kinerja reksa dana yang telah diperoleh dibandingkan dengan portofolio pembanding. Menurut Manurung (2008) oleh Sulistyorini (2009) dalam melakukan evaluasi kinerja portofolio berhubungan dengan dua persoalan mendasar yaitu:

a Penentuan apakah manajer investasi menambah nilai terhadap portofolio dibandingkan dengan pembanding (benchmark).

b Penentuan perhitungan tingkat pengembalian tersebut.

Sumber informasi utama dalam pengukuran kinerja adalah nilai aktiva bersih per unit penyertaan (NAB/unit) atau harga per unit. Perubahan NAB/unit menjadi indikator kinerja investasi suatu reksa dana. Data NAB/unit sering diolah kembali oleh beberapa peneliti untuk memperoleh gambaran kinerja reksa dalam rentang periode tertentu, misalkan satu bulan, satu tahun atau bahkan sejak reksa dana tersebut didirikan, namun dalam proses pengukuran kinerja inilah, sering ditemukan kesalahan yang justru dapat merugikan investor. Kesalahan yang sering ditemukan dalam kinerja reksa dana antara lain berkaitan dengan hal-hal berikut ini (Pratomo dan Ubaidillah, 2002):

a Menilai kinerja berdasarkan pertumbuhan dana. 
b Menghitung kinerja reksa dana tanpa memperhatikan adanya pembagian keuntungan (dividen).

c Membandingkan kinerja reksa dana untuk periode yang berbeda serta tidak menggunakan tolak ukur (benchmark) yang sesuai.

d Membandingkan kinerja reksa dana yang mempunyai portofolio investasi berlainan.

Ada beberapa metode pengukuran kinerja reksa dana dengan memasukkan unsur resiko dan return, yang sering digunakan yakni dengan indeks Sharpe, Treynor dan Jensen. Pada penelitian ini akan digunakan metode Sharpe, Treynor dan Jensen.

1. Metode Sharpe

Salah satu metode yang digunakan untuk membandingkan kinerja portofolio yaitu Indeks Sharpe. Indeks Sharpe ini menggunakan konsep dari Garis Pasar Modal (capital market line) dimana Sharpe menyatakan series kinerja portofolio dihitung merupakan hasil bersih dari portofolio dengan tingkat bunga bebas risiko per unit risiko dengan diberi simbol Sp (Manurung, 2008 dalam Sulistyorini, 2009). Indeks kinerja Sharpe dihitung dengan formula berikut (Sharpe, 1966 dalam Sulistyorini, 2009):

$$
\mathrm{S}_{\mathrm{RD}}=\frac{\text { Kinerja }_{\mathrm{RD}}-\text { Kinerja }_{\mathrm{RF}}}{\sigma}
$$

Keterangan:

SRD

: Nilai Rasio Sharpe

Kinerja RD

: Kinerja Reksa Dana

Kinerja $\mathrm{RF}$

: Kinerja investasi bebas risiko

$\sigma$

: Standar Deviasi Reksa dana

$$
\text { Kinerja }_{\mathrm{RD}}=\frac{\mathrm{NAK}-\mathrm{NAW}}{\mathrm{NAW}}
$$

Keterangan:

$$
\begin{array}{ll}
\begin{array}{l}
\text { Kinerja RD } \\
\text { NAK }
\end{array} & \begin{array}{l}
\text { : Kinerja Reksa Dana } \\
\text { NAW }
\end{array} \\
& \text { Nilai Aktiva Bersih/ unit akhir bulan ini } \\
& \text { Kinerja }_{\mathrm{RF}}=\frac{\mathrm{R}_{\mathrm{F} 1 \mathrm{t}}+\mathrm{R}_{\mathrm{F} 2 \mathrm{t}}+\mathrm{R}_{\mathrm{Fnt}}}{\mathrm{n}} \\
\text { Keterangan: } & \\
\begin{array}{l}
\text { Kinerja } \mathrm{RF} \\
\text { RF1t, RF2t, RFnt }
\end{array} & \begin{array}{l}
\text { : Kinerja investasi bebas risiko } \\
\mathrm{n}
\end{array}
\end{array}
$$

Rumus untuk mengitung standar deviasi adalah sebagai berikut: 


$$
S=\sqrt{\frac{\Sigma(X-X)^{2}}{n-1}}
$$

Keterangan:

S : Standar deviasi sampel

$\Sigma$ : Simbol dari operasi penjumlahan

$\mathrm{X}$ : Nilai return data yang berada dalam sampel X : Rata-rata hitung sampel (expected return)

$\mathrm{n}$ : Jumlah total data

Keterangan:

$$
\overline{\mathrm{X}}=\frac{\Sigma \mathrm{X}}{\mathrm{n}}
$$

X: Rata-rata hitung sampel (expected return) $\Sigma$ : Simbol dari operasi penjumlahan

$\mathrm{n}$ : Jumlah total data

Hasil perhitungan kinerja portfolio dengan indeks Sharpe yang positif dan berada diatas pasar menandakan portfolio tersebut memiliki kinerja yang baik. Jika hasil perhitungan kinerja portfolio dengan indeks Sharpe menunjukkan angka yang lebih kecil dari nilai portfolio pasar, maka portfolio tersebut memiliki kinerja yang buruk.

\section{Metode Treynor}

Treynor sebagai salah satu indeks yang digunakan untuk mengukur kinerja portofolio, Treynor mengamsusikan bahwa portofolio sudah mempunyai diversifikasi yang baik. Oleh karena itu, Indeks Treynor menyatakan series kinerja portofolio dihitung merupakan hasil bersih dari portofolio dengan tingkat bunga bebas risiko per unit risiko pasar portofolio tersebut, dengan diberi simbol Tp (Manurung, 2008 dalam Sulistyorini, 2009).

Indeks kinerja Treynor dihitung dengan formula berikut:

Keterangan:

$$
\mathrm{T}_{\mathrm{RD}}=\frac{\text { Kinerja }_{\mathrm{Rd}}-\text { Kinerja }_{\mathrm{RF}}}{\beta}
$$

$\begin{array}{ll}\text { TRD } & \text { : Nilai Rasio Treynor } \\ \text { Kinerja RD } & \text { : Kinerja Reksa Dana } \\ \text { Kinerja } \mathrm{RF} & \text { : Kinerja investasi bebas risiko } \\ \beta & : \text { Beta atau risiko sistematik suatu portofolio (korelasi } \\ & \text { NAB per unit reksa dana dengan price indeks pasar IHSG } \\ & \text { dan LQ45) }\end{array}$

Keterangan:

$$
\text { Kinerja }_{\mathrm{RD}}=\frac{\mathrm{NAK}-\mathrm{NAW}}{\mathrm{NAW}}
$$

Kinerja RD

: Kinerja Reksa Dana

NAK

: Nilai Aktiva Bersih/ unit akhir bulan ini

NAW

: Nilai Aktiva Bersih/ unit akhir bulan sebelumnya 
Keterangan:

$$
\text { Kinerja }_{\mathrm{RF}}=\frac{\mathrm{R}_{\mathrm{F} 1 \mathrm{t}}+\mathrm{R}_{\mathrm{F} 2 \mathrm{t}}+\mathrm{R}_{\mathrm{Fnt}}}{\mathrm{n}}
$$

Kinerja $R F$

: Kinerja investasi bebas risiko

RF1t , RF2t , RFnt

: Suku bunga SBI periode $t$

$\mathrm{n}$

: Jumlah periode pengamatan

3. Metode Jensen

Dalam pendekatan Jensen menunjukan perbedaan antara tingkat return aktual yang diperoleh portofolio dengan tingkat return harapan jika portofolio tersebut berada pada garis pasar modal. Indeks Jensen adalah kelebihan return di atas atau di bawah garis pasar sekuritas. Indeks Jensen secara mudahnya dapat diinterpretasikan sebagai pengukur berapa banyak portofolio "mengalahkan pasar". Indeks yang bernilai positif berarti portofolio memberi return yang lebih besar dari return harapannya (berada di atas garis pasar sekuritas) sehingga merupakan hal yang bagus karena portofolio mempunyai return yang relatif tinggi untuk tingkat resiko sistematisnya. Demikian juga sebaliknya, indeks yang bernilai negatif menunjukan bahwa portofolio mempunyai return yang relatif rendah untuk tingkat risiko sistematisnya. Dapat dirumuskan:

$$
\begin{aligned}
& (\text { Kinerja } \mathrm{RD}-\text { Kinerja } \mathrm{RF})=\text { Alfa }+\beta \times(\text { Kinerja } \mathrm{RP}-\text { Kinerja } \mathrm{RF}) \\
& \quad \text { atau } \\
& \text { Alfa = (Kinerja } \mathrm{RD}-\text { Kinerja } \mathrm{RF})-\beta \times(\text { Kinerja } \mathrm{RP}-\text { Kinerja } \mathrm{RF})
\end{aligned}
$$

Keterangan:

Alfa

Kinerja RP

: Nilai perpotongan Jensen

$\beta$

\section{: KIHSG dan K LQ 45}

:Beta atau risiko sistematik suatu portofolio (korelasi NAB per unit reksa dana dengan price indeks pasar IHSG dan LQ45)

Keterangan:

$$
\text { Kinerja }_{\text {RD }}=\frac{N A K-N A W}{N A W}
$$

Kinerja RD : : Kinerja Reksa Dana

NAK : Nilai Aktiva Bersih/ unit akhir bulan ini

NAW : Nilai Aktiva Bersih/ unit akhir bulan sebelumnya

Keterangan:

$$
\text { Kinerja }_{\mathrm{RF}}=\frac{\mathrm{R}_{\mathrm{F} 1 \mathrm{t}}+\mathrm{R}_{\mathrm{F} 2 \mathrm{t}}+\mathrm{R}_{\mathrm{Fnt}}}{\mathrm{n}}
$$

Kinerja $\mathrm{RF} \quad$ : Kinerja investasi bebas risiko

RF1t, RF2t, RFnt : Suku bunga SBI periode $t$

$\mathrm{n}$

$$
\text { : Jumlah periode pengamatan }
$$




\section{METODOLOGI PENELITIAN}

Penelitian ini menggunakan pendekatan deskriptif dan statistik, yang merupakan studi kasus terhadap produk reksa dana saham di Indonesia yang ada pada periode Januari 2009 sampai Desember 2013. Selanjutnya dilakukan pengolahan terhadap kinerja pada investasi reksa dana saham dari para manajer investasiyang mengelola produk reksa dana itu dengan menggunakan metode Sharpe, Treynor dan Jensen dengan return IHSG dan LQ 45 sebagai pembanding dan diasumsikan tingkat suku bunga ratarata sebagai risk free rate.

\section{POPULASI DAN SAMPEL}

Dalam penulisan skripsi ini, penulis menggunakan metode purposive sampling yaitu pengambilan sampel yang menyesuaikan diri dengan kriteria tertentu. Jadi, penulis tidak mengambil semua produk reksa dana sebagai objek penulisan tetapi hanya yang memenuhi syarat-syarat sebagai berikut:

1. Reksa dana yang dipilih adalah jenis reksa dana saham konvensional,

2. Sampel yang diambil merupakan reksa dana yang ditawarkan pada periode 2009 sampai dengan 2013 dan masih aktif hingga saat ini.

3. Sampel yang diambil merupakan produk dari perusahaan reksa dana yang aktif selama tahun 2009 sampai dengan 2013 dan memiliki Nilai Aktiva Bersih (NAB) yang dipublikasikan.

4. Data Nilai Aktiva Bersih (NAB) reksa dana yang akan diambil sebagai sampel penulisan ini adalah data bulanan tahun yang bersangkutan.

5. Tingkat suku bunga dilaporkan dalam SBI.

\section{TEKNIK ANALISIS DATA}

Metode analisis data yang digunakan dalam penelitian ini adalah analisis deskriptif kuantitatif. Dalam menganalisis data mentah tersebut penulis menggunakan beberapa rumus sehingga data tersebut nantinya dapat dimasukan dalam perhitungan. selanjutnya, antara lain:

1. Rumus Nilai Aktiva Bersih (NAB)

Nilai aktiva bersih (NAB) merupakan jumlah aktiva setelah dikurangi kewajiban-kewajiban yang ada. Sedangkan NAB per unit penyertaan merupakan jumlah NAB dibagi dengan jumlah nilai unit penyertaan yang beredar.

2. Rumus Risk Free Rate

$$
\mathrm{NAB}=\frac{(\text { Jumlah Aset }- \text { Total Kewajiban) }}{\text { Jumlah Unit Penyertaan }}
$$

Dalam penelitian ini, investasi tanpa risiko diasumsikan merupakan tingkat suku bunga rata-rata dari Sertifikat Bank Indonesia (SBI). Kinerja investasi bebas risiko pada sub periode dirumuskan sebagai berikut:

Keterangan:

$$
\text { Kinerja }_{\mathrm{RF}}=\frac{\mathrm{R}_{\mathrm{F} 1 \mathrm{t}}+\mathrm{R}_{\mathrm{F} 2 \mathrm{t}}+\mathrm{R}_{\mathrm{Fnt}}}{\mathrm{n}}
$$

Kinerja $\mathrm{RF} \quad$ : Kinerja investasi bebas risiko RF1t, RF2t, RFnt : Suku bunga SBI periode $t$

$\mathrm{n} \quad$ : Jumlah periode pengamatan

3. Rumus tingkat pengembalian reksa dana (returnreksa dana) 
Nilai ini diperoleh dari angka NAB per unit penyertaan untuk masingmasing reksa dana saham yang diteliti, dengan rumus:

Keterangan:

$$
\text { Kinerja } \mathrm{RD}_{\mathrm{RD}}=\frac{\mathrm{NAK}-\mathrm{NAW}}{\mathrm{NAW}}
$$

Kinerja RD : Kinerja Reksa Dana

NAK : Nilai Aktiva Bersih/ unit akhir bulan ini

NAW : Nilai Aktiva Bersih/ unit akhir bulan sebelumnya

4. Mencari resiko investasi reksa dana dengan menggunakan rumus standar deviasi.

$$
S=\sqrt{\frac{\sum(\mathrm{X}-\overline{\mathrm{X}})^{2}}{\mathrm{n}-1}}
$$

Keterangan:

S : Standar deviasi sampel

$\Sigma$ : Simbol dari operasi penjumlahan

$\mathrm{X}$ : Nilai return data yang berada dalam sampel X : Rata-rata hitung sampel

- (expected return)

$\mathrm{n}$ : Jumlah total data

Keterangan:

$$
\overline{\mathrm{X}}=\frac{\Sigma \mathrm{X}}{\mathrm{n}}
$$

X: Rata-rata hitung sampel (expected return) $\Sigma$ : Simbol dari operasi penjumlahan

$\mathrm{n}$ : Jumlah total data

5. Rumus tingkat pengembalian pasar IHSG dan LQ45

Keterangan:

$$
\mathrm{K}_{\mathrm{IHSG}}=\frac{\mathrm{IHSG}_{\mathrm{t}}-\mathrm{IHSG}_{\mathrm{t}-1}}{\mathrm{IHSG} \mathrm{t}_{\mathrm{t}-1}}
$$

K IHSG

: Return IHSG

IHSG t

: Return Pasar IHSG periode ini

IHSG $\mathrm{t}-1$

: Return pasar IHSG periode sebelumnya

Keterangan:

$$
\mathrm{K}_{\mathrm{LQ45}}=\frac{\mathrm{K}_{\mathrm{LQ45t}}-\mathrm{K}_{\mathrm{LQ45t}-1}}{\mathrm{~K}_{\mathrm{LQ45t-1}}}
$$

K LQ 45 : Return LQ45

LQ $45 \mathrm{t} \quad$ : Return Pasar LQ45 periode ini

LQ 45 t-1: Return pasar LQ45 periode sebelumnya

6. Perhitungan Kinerja Berdasarkan Metode Sharpe, Treynor, Dan Jensen

a. Indeks Sharpe

Dalam penggunaan metode Sharpe, kinerja reksa dana dihitung tanpa memperhatikan pasarnya dan hanya didasarkan pada penyimpangan dari portofolio reksa dana tersebut. Langkah pengerjaan indeks Sharpe adalah sebagai berikut: 
a) Menghitung terlebih dahulu return dari portofolio reksa dana yang diperoleh dengan cara menselisihkan antara NAB per unit penyertaan tahun sekarang dengan NAB per unit penyertaan tahun sebelumnya (Rumus KinerjaRD).

b) Masing-masing portofolio reksa dana tersebut, langkah berikutnya adalah mencari standar deviasi untuk masing-masing reksa dana tersebut dengan program excel. Data berikutnya yang juga dibutuhkan dalam perhitungan ini adalah data risk free rate (RF) yang diperoleh dari tingkat suku bunga BI (Rumus Kinerja $\mathrm{RF}$ )

c) Langkah terakhir adalah memasukkan data-data tersebut ke dalam rumus sebagai berikut:

$$
\mathrm{S}_{\mathrm{RD}}=\frac{\text { Kinerja }_{\mathrm{RD}}-\text { Kinerja }_{\mathrm{RF}}}{\sigma}
$$

Keterangan:

SRD

: Nilai Ratio Sharpe

Kinerja RD : : Kinerja reksa dana

Kinerja $\mathrm{RF} \quad$ : Kinerja investasi bebas risiko

$\sigma \quad$ : Standar deviasi reksa dana

Dengan bantuan program excel, penulis dapat memperoleh nilai indeks Sharpe untuk masing-masing reksa dana.

b. Indeks Treynor

Dalam penggunaan metode Treynor, kinerja reksa dana dihitung dengan memperhatikan fluktuasi pasarnya. Langkah pengerjaan indeks Treynor adalah sebagai berikut:

a) Menghitung return portofolio reksa dana untuk masing-masing reksa dana yang pengerjaannya sama seperti dalam indeks Sharpe.

b) Melakukan regresi sedehana untuk mencari beta $(\beta)$ yang merupakan fluktuasi relatif terhadap risiko pasar. Dalam mencari beta korelasi antara NAB/unit reksa dana dengan price index pasar IHSG dan LQ45 c) Langkah terakhir adalah memasukan data tersebut kedalam rumus sebagai berikut:

$$
\mathrm{T}_{\mathrm{RD}}=\frac{\text { Kinerja }_{\mathrm{Rd}}-\text { Kinerja }_{\mathrm{RF}}}{\beta}
$$

Keterangan:

TRD

: Nilai rasio Treynor

Kinerja RD : Kinerja reksa dana

Kinerja $\mathrm{RF} \quad$ : Kinerja investasi bebas risiko

B :Beta atau risiko sistematik suatu portofolio (Korelasi $\mathrm{NAB} /$ unit reksa dana dengan price index pasar IHSG dan LQ45) 
Dengan bantuan program excel, penulis dapat memperoleh nilai indeks Treynor untuk masing-masing reksa dana.

c. Indeks Jensen

Pengukuran metode ini untuk menilai kinerja manajer investasi apakah mampu memberikan kinerja diatas kinerja pasar sesuai risiko yang dimilikinya. Langkah pengerjaan indeks Jensen adalah sebagai berikut:

a) Langkah pengerjaannya sama seperti Treynor, tetapi untuk mengukur indeks Jensen dilakukan penyelisihan antara return portofolio (reksa dana) terhadap return bebas risiko (SBI) lalu dikurangi dengan hasil dari beta (korelasi NAB/unit reksa dana dengan price index pasar IHSG dan LQ45) yang dikalikan dengan selisih antara return pasar (IHSG dan LQ45) terhadap return bebas resiko (SBI).

$($ Kinerja $\mathrm{RD}-$ Kinerja $\mathrm{RF})=\mathrm{Alfa}+\beta \mathrm{x}($ Kinerja $\mathrm{RP}-$ Kinerja $\mathrm{RF})$ Atau

$\mathrm{Alfa}=($ Kinerja $\mathrm{RD}-$ Kinerja $\mathrm{RF})-\beta \mathrm{x}($ Kinerja $\mathrm{RP}-$ Kinerja $\mathrm{RF})$ Keterangan:

Alfa : Nilai perpotongan Jensen

Kinerja RP : KIHSG dan K LQ 45

\section{HASIL PENELITIAN}

\section{Penilaian Berdasarkan Expected Return}

Dari 29 reksa dana yang menjadi sampel penelitian penulis, dipilihlah lima reksa dana yang memiliki expected return tertinggi dan lima yang memiliki expected return terendah (ditandai dengan warna merah) setiap tahun dari tahun 2009 sampai 2013, berikut hasilnya:

Tabel 1. Deskriptik Statistik Excpected Return 2009

\begin{tabular}{|l|l|l|}
\hline INDEK PASAR & KODE & $\begin{array}{c}\text { EXPECTED } \\
\text { RETURN } \\
\mathbf{2 0 0 9}\end{array}$ \\
\hline IHSG & IHSG & 0.0599 \\
\hline LQ 45 & LQ 45 & 0.0595 \\
\hline REKSA DANA SAHAM & & \\
\hline Pratama Saham & 0099424 & 0.0949 \\
\hline Reksa Dana TRIM Kapital Plus & 000D2L & 0.0915 \\
\hline Panin Dana Prima & GR002PRIMASH & 0.0841 \\
\hline Reksa Dana BNP Paribas Solaris & F0SL & 0.0804 \\
\hline Reksa Dana Makinta Mantap & 00D68D & 0.0801 \\
\hline Rencana Cerdas & 0091017 & 0.0607 \\
\hline Reksa Dana Millenium Equity & 00D61B & 0.0602 \\
\hline FS Indoequity Dividend Yield Fund & 035600048431 & 0.0575 \\
\hline Reksa Dana Makinta Growth Fund & 00D68B & 0.0576 \\
\hline Reksa Dana MNC Dana Ekuitas & BIG-EQ & 0.0407 \\
\hline
\end{tabular}

Sumber: Hasil Pengolahan Data

Dari tabel 1 yang menunjukan expected return tahun 2009, lima reksa dana yang memiliki expected return tertinggi dan lima reksa dana yang memiliki expected return 
terendah, reksa dana yang memiliki expected return tertinggi untuk tahun 2009 adalah reksa dana Pratama Saham sebesar 0.0949 yang mampu outperform dari IHSG sebesar 0.0599 dan LQ45 sebesar 0.0595, untuk reksa dana yang memiliki expected return terendah adalah Reksa Dana MNC Dana Ekuitas sebesar 0.0407, namun reksa dana Rencana Cerdas dan Reksa Dana Millenium Equity yang termasuk lima reksa dana yang memiliki expected return terendah justru memiliki expected return di atas expected return IHSG dan LQ45 dan mampu outperform, hal ini dapat disebabkan perolehan expected return yang tinggi reksa dana dan cukup jauh berbeda dari IHSG dan LQ45.

Tabel 2. Deskriptik Statistik Expected Return 2010

\begin{tabular}{|l|l|l|}
\hline INDEK PASAR & KODE & $\begin{array}{c}\text { EXPECTED } \\
\text { RETURN } \\
\mathbf{2 0 1 0}\end{array}$ \\
\hline IHSG & IHSG & 0.0243 \\
\hline LQ 45 & LQ 45 & 0.0151 \\
\hline REKSA DANA SAHAM & & \\
\hline Reksa Dana MNC Dana Ekuitas & BIG-EQ & 0.0317 \\
\hline Panin Dana Prima & GR002PRIMASH & 0.0315 \\
\hline Syailendra Equity Opportunity Fund & 0085290 & 0.0255 \\
\hline BNP Paribas Ekuitas & 0089763 & 0.0234 \\
\hline Grow-2-Prosper & 0086504 & 0.0228 \\
\hline Reksa Dana Simas Danamas Saham & $000 D 80$ & 0.0129 \\
\hline CIMB-Principal Equity Aggressive & 0099556 & 0.0123 \\
\hline $\begin{array}{l}\text { First State Indoequity Value Select } \\
\text { Fund }\end{array}$ & 0085100 & 0.0110 \\
\hline Reksa Dana Makinta Mantap & $00 \mathrm{D} 68 \mathrm{D}$ & 0.0107 \\
\hline Reksa Dana Millenium Equity & $00 \mathrm{D} 61 \mathrm{~B}$ & 0.0024 \\
\hline
\end{tabular}

Sumber: Hasil Pengolahan Data

Tabel 2 menunjukkan hasil expected return reksa dana untuk tahun 2010, lima reksa dana yang memiliki expected return tertinggi dan lima reksa dana memiliki expected return yang terendah. Tahun 2010 Reksa Dana MNC Dana Ekuitas memiliki expected return tertinggi sebesar 0.0317 dan mampu outperform dari IHSG sebesar 0.0243 dan LQ45 sebesar 0.0151, sangat berbeda dari tahun sebelumnya Reksa Dana MNC Dana Ekuitas memiliki expected return yang terendah, kenaikan drastis ini dapat disebabkan prospek perusahaan, karena harga saham sangat fluktuatif dan sangat dipengaruhi oleh prospek perusahaan. Pada tahun 2010 reksa dana yang memiliki expected return terendah adalah Reksa Dana Millenium Equity sebesar 0.0024.

Tabel 3. Deskriptif Statistik Expected Return 2011

\begin{tabular}{|l|l|l|}
\hline INDEK PASAR & KODE & $\begin{array}{c}\text { EXPECTED } \\
\text { RETURN } \\
\mathbf{2 0 1 1}\end{array}$ \\
\hline IHSG & IHSG & 0.0132 \\
\hline LQ 45 & LQ 45 & 0.0135 \\
\hline REKSA DANA SAHAM & & \\
\hline Reksa Dana Makinta Mantap & 00D68D & 0.0331 \\
\hline TRIM Kapital & 000D2B & 0.0217 \\
\hline Reksa Dana TRIM Kapital Plus & 000D2L & 0.0214 \\
\hline
\end{tabular}




\begin{tabular}{|l|l|l|}
\hline Reksa Dana Makinta Growth Fund & 00D68B & 0.0185 \\
\hline Reksa Dana Schroder Dana Istimewa & 006600829471 & 0.0170 \\
\hline $\begin{array}{l}\text { Reksa Dana BNP Paribas Insfrastruktur } \\
\text { Plus }\end{array}$ & FOIP & 0.0055 \\
\hline Grow-2-Prosper & 0086504 & 0.0052 \\
\hline Reksa Dana Simas Danamas Saham & $000 \mathrm{D} 80$ & 0.0034 \\
\hline Pratama Saham & 0099424 & 0.0027 \\
\hline Batavia Dana Saham Agro & 0085001 & -0.0147 \\
\hline
\end{tabular}

Sumber: Hasil Pengolahan Data

Tabel 3 menunjukkan expected return reksa dana, IHSG dan LQ45 untuk tahun 2011, Reksa Dana Makinta Mantap memiliki expected return tertinggi dari lima reksa dana yang memiliki expected return tertinggi yaitu sabesar 0.0331 dan mampu outperform dibanding IHSG dan LQ45 sebesar 0.0132 untuk IHSG dan 0.0135 untuk LQ45. Di samping itu Reksa Dana TRIM Kapital Plus tetap termasuk salah satu reksa dana yang memiliki expected return tertinggi sebesar 0.0214 dan masih mampu outperform dari IHSG dan LQ45, untuk reksa dana yang memiliki expected return terendah yaitu Batavia Dana Saham Agro yang mempunyai expected return yang negatif sebesar -0.0147 .

Tabel 4. Deskriptif Statistik Expected Return 2012

\begin{tabular}{|l|l|l|}
\hline INDEK PASAR & KODE & $\begin{array}{c}\text { EXPECTED } \\
\text { RETURN } \\
\mathbf{2 0 1 2}\end{array}$ \\
\hline IHSG & IHSG & 0.0109 \\
\hline LQ 45 & LQ 45 & 0.0088 \\
\hline REKSA DANA SAHAM & & \\
\hline Reksa Dana MNC Dana Ekuitas & BIG-EQ & 0.0212 \\
\hline Syailendra Equity Opportunity Fund & 0085290 & 0.0191 \\
\hline Reksa Dana BNP Paribas Solaris & FOSL & 0.0150 \\
\hline Batavia Dana Saham Optimal & 0086769 & 0.0140 \\
\hline Reksa Dana TRIM Kapital Plus & 000D2L & 0.0136 \\
\hline CIMB-Principal Equity Aggressive & 0099556 & 0.0044 \\
\hline Reksa Dana NISP Indeks Saham Progresif & NISP & 0.0043 \\
\hline Schroder Dana Prestasi Plus & 0090829 & 0.0043 \\
\hline Reksa Dana Simas Danamas Saham & $000 D 80$ & -0.0047 \\
\hline Batavia Dana Saham Agro & 0085001 & -0.0100 \\
\hline
\end{tabular}

Sumber: Hasil Pengolahan Data

Tabel 4 menunjukkan hasil perhitungan expected return reksa dana , IHSG dan LQ45 untuk tahun 2012, dari lima reksa dana ynag memiliki expected return tertinggi, sama dengan tahun 2010 Reksa Dana MNC Dana Ekuitas kembali memiliki expected return paling tinggi sebesar 0.0212 dan mampu outperform dari IHSG sebesar 0.0109 dan LQ45 sebesar 0.0088, di samping itu Reksa Dana TRIM Kapital Plus sebesar 0.0136 masih termasuk pada reksa dana yang memiliki expected return tertinggi dan masih mampu outperform dari IHSG dan LQ 45, untuk reksa dana yang memiliki expected return terendah masih sama dengan tahun sebelumnya yaitu Batavia Dana 
Tabel 5 Deskriptif Statistik Expected Return 2015

\begin{tabular}{|l|l|l|}
\hline INDEK PASAR & KODE & $\begin{array}{c}\text { EXPECTED } \\
\text { RETURN } \\
\mathbf{2 0 1 3}\end{array}$ \\
\hline IHSG & IHSG & 0.0005 \\
\hline LQ 45 & LQ 45 & -0.0009 \\
\hline REKSA DANA SAHAM & & \\
\hline Reksa Dana Millenium Equity & $00 \mathrm{D} 61 \mathrm{~B}$ & 0.0507 \\
\hline Pratama Saham & 0099424 & 0.0146 \\
\hline Grow-2-Prosper & 0086504 & 0.0134 \\
\hline Batavia Dana Saham Optimal & 0086769 & 0.0064 \\
\hline Batavia Dana Saham & BAM SAH & 0.0057 \\
\hline Rencana Cerdas & 0091017 & -0.0083 \\
\hline Reksa Dana Mandiri Investa Atraktif & 035600055431 & -0.0078 \\
\hline Reksa Dana TRIM Kapital Plus & 000D2L & -0.0110 \\
\hline BNI Reksadana Berkembang & $000 \mathrm{D} 1 \mathrm{~B}$ & -0.0112 \\
\hline Batavia Dana Saham Agro & 0085001 & -0.0161 \\
\hline Sumber: Hasil Pengolahan Data & & \\
\hline
\end{tabular}

Sumber: Hasil Pengolahan Data

Tabel di atas menunjukkan expected return reksa dana, IHSG dan LQ45 untuk tahun 2013, dari lima reksa dana yang memiliki expected return tertinggi, Reksa Dana Millenium Equity memiliki expected return paling tinggi sebesar 0.0507 dan mampu outperform dari IHSG sebesar 0.0005 dan LQ45 sebesar -0.0009, untuk reksa dana yang memiliki expected return terendah masih Batavia Dana Saham Agro dengan expected return negatif sebesar -0.0161 .

\section{Penilaian Berdasarkan Metode Sharpe}

Dari 29 reksa dana yang menjadi sampel penelitian penulis, dipilihlah lima reksa dana yang memiliki nilai paling tinggi jika di ukur menggunakan metode Sharpe dan lima yang memiliki nilai terendah (ditandai dengan warna merah) setiap tahun dari tahun 2009 sampai 2013, berikut hasilnya:

Tabel 6 Kinerja Reksa Dana Metode Sharpe 2009

\begin{tabular}{|l|l|c|}
\hline \multicolumn{1}{|c|}{ INDEK PASAR } & \multicolumn{1}{c|}{ KODE } & SHARPE \\
\hline IHSG & IHSG & 0.7769 \\
\hline LQ 45 & LQ 45 & 0.7184 \\
\hline REKSA DANA SAHAM & & \\
\hline Reksa Dana MNC Dana Ekuitas & BIG-EQ & 0.9391 \\
\hline Schroder Dana Prestasi Plus & 0090829 & 0.7659 \\
\hline Reksa Dana TRIM Kapital Plus & 000D2L & 0.7621 \\
\hline Panin Dana Prima & GR002PRIMASH & 0.7723 \\
\hline Reksa Dana Schroder Dana Istimewa & 006600829471 & 0.7714 \\
\hline Reksa Dana Makinta Growth Fund & 00D68B & 0.6024 \\
\hline Batavia Dana Saham Agro & 0085001 & 0.5653 \\
\hline Syailendra Equity Opportunity Fund & 0085290 & 0.5252 \\
\hline Reksa Dana Makinta Mantap & 00D68D & 0.4885 \\
\hline BNI Reksadana Berkembang & 000D1B & 0.4395 \\
\hline
\end{tabular}

Sumber: Hasil Pengolahan Data 
Tabel 6 menunjukkan hasil perhitungan kinerja reksa dana, IHSG dan LQ45 menggunakan metode Sharpe, untuk tahun 2009 Reksa Dana MNC Dana Ekuitas sebesar 0.9391 memiliki kinerja paling baik dari lima reksa dana yang memiliki kinerja tertinggi dan mampu outperform dari IHSG sebesar 0.7769 dan LQ45 sebesar 0.7184, untuk reksa dana yang memiliki kinerja terendah adalah BNI Reksadana Berkembang sebesar 0.4395

Tabel 7 Kinerja Reksa Dana Metode Sharpe 2010

\begin{tabular}{|l|l|l|}
\hline INDEK PASAR & KODE & SHARPE \\
\hline IHSG & IHSG & 0.3117 \\
\hline LQ 45 & LQ 45 & 0.1582 \\
\hline REKSA DANA SAHAM & & \\
\hline Panin Dana Prima & GR002PRIMASH & 0.3851 \\
\hline Reksa Dana MNC Dana Ekuitas & BIG-EQ & 0.3779 \\
\hline Syailendra Equity Opportunity Fund & 0085290 & 0.3045 \\
\hline BNP Paribas Ekuitas & 0089763 & 0.3007 \\
\hline Grow-2-Prosper & 0086504 & 0.2443 \\
\hline First State Indoequity Sectoral Fund & 0098566 & 0.1542 \\
\hline Reksa Dana Makinta Growth Fund & 00D68B & 0.1221 \\
\hline CIMB-Principal Equity Aggressive & 0099556 & 0.1140 \\
\hline Reksa Dana Makinta Mantap & 00D68D & 0.0645 \\
\hline Reksa Dana Millenium Equity & 00D61B & -0.0450 \\
\hline
\end{tabular}

Sumber: Hasil Pengolahan Data

Tabel 7 menunjukkan hasil perhitungan kinerja reksa dana, IHSG dan LQ45 menggunakan metode Sharpe untuk tahun 2010, dari lima reksa dana yang memiliki kinerja tertinggi reksa dana Panin Dana Prima memiliki kinerja paling tinggi sebesar 0.3851 dan mampu outperform dari IHSG sebesar 0.3117 dan LQ45 sebesar 0.1582, di samping itu Reksa Dana MNC Dana Ekuitas juga memiliki kinerja yang cukup baik sebesar 0.3779 karena termasuk pada reksa dana yang memiliki kinerja tertinggi serta mampu outperform dari IHSG dan LQ45, untuk reksa dana yang memiliki kinerja terendah adalah Reksa Dana Millenium Equity yang memiliki kinerja yang negatif sebesar -0.0450 .

Tabel 8. Tabel 7 Kinerja Reksa Dana Metode Sharpe 2011

\begin{tabular}{|l|l|l|}
\hline INDEK PASAR & KODE & SHARPE \\
\hline IHSG & IHSG & 0.1682 \\
\hline LQ 45 & LQ 45 & 0.1606 \\
\hline REKSA DANA SAHAM & & \\
\hline Reksa Dana Makinta Mantap & 00D68D & 0.3917 \\
\hline TRIM Kapital & 000D2B & 0.2840 \\
\hline Reksa Dana TRIM Kapital Plus & 000D2L & 0.2470 \\
\hline Reksa Dana Millenium Equity & 00D61B & 0.2177 \\
\hline Reksa Dana Makinta Growth Fund & 00D68B & 0.2070 \\
\hline Reksa Dana BNP Paribas Insfrastruktur Plus & FOIP & -0.0017 \\
\hline Grow-2-Prosper & 0086504 & -0.0058 \\
\hline
\end{tabular}




\begin{tabular}{|l|l|l|}
\hline Reksa Dana Simas Danamas Saham & $000 \mathrm{D} 80$ & -0.0315 \\
\hline Pratama Saham & 0099424 & -0.0374 \\
\hline Batavia Dana Saham Agro & 0085001 & -0.2812 \\
\hline
\end{tabular}

Sumber: Hasil Pengolahan Data

Tabel 8 menunjukkan hasil perhitungan kinerja reksa dana, IHSG dan LQ45 menggunakan metode Sharpe untuk tahun 2011, dari lima reksa dana yang memiliki kinerja tertinggi, Reksa Dana Makinta Mantap memiliki kinerja paling tinggi sebesar 0.3917 dan mampu outperform dari IHSG sebesar 0.1682 dan LQ45 sebesar 0.1606, untuk reksa dana yang memiliki kinerja lima terendah rata-rata semuanya memiliki nilai yang negatif namun kinerja yang paling rendah adalah Batavia Dana Saham Agro dengan nilai negatif sebesar -0.2812 .

Tabel 9. Kinerja Reksa Dana Metode Sharpe 2012

\begin{tabular}{|l|l|l|}
\hline INDEK PASAR & KODE & $\begin{array}{l}\text { SHARPE } \\
\mathbf{2 0 1 2}\end{array}$ \\
\hline IHSG & IHSG & 0.1717 \\
\hline LQ 45 & LQ 45 & 0.0980 \\
\hline REKSA DANA SAHAM & & \\
\hline Syailendra Equity Opportunity Fund & 0085290 & 0.3909 \\
\hline Reksa Dana MNC Dana Ekuitas & BIG-EQ & 0.3672 \\
\hline Reksa Dana BNP Paribas Solaris & FOSL & 0.2634 \\
\hline Panin Dana Prima & GR002PRIMASH & 0.2107 \\
\hline Reksa Dana BNP Paribas Insfrastruktur Plus & FOIP & 0.2043 \\
\hline Schroder Dana Prestasi Plus & 0090829 & -0.0133 \\
\hline Reksa Dana NISP Indeks Saham Progresif & NISP & -0.0120 \\
\hline CIMB-Principal Equity Aggressive & 0099556 & -0.0103 \\
\hline Reksa Dana Simas Danamas Saham & $000 D 80$ & -0.1827 \\
\hline Batavia Dana Saham Agro & 0085001 & -0.2412 \\
\hline
\end{tabular}

Sumber: Hasil Pengolahan Data

Tabel 9 menunjukkan lima kinerja reksa dana tertinggi dan lima kinerja reksa dana terendah yang diukur menggunkan metode Sharpe untuk tahun 2012, kinerja reksa dana Syailendra Equity Opportunity Fund memiliki kinerja paling tinggi sebesar 0.3909 dan mampu outperform dari IHSG sebesar 0.1717 dan LQ45 sebesar 0.0980, di samping itu terdapat pula Reksa Dana MNC Dana Ekuitas yang termasuk pada lima reksa dana yang memiliki kinerja tertinggi serta mampu outperform dari IHSG dan LQ45 yaitu sebesar 0.3672. untuk reksa dana yang memiliki kinerja paling rendah masih reksa dana Batavia Dana Saham Agro yang memiliki nilai yang negatif yaitu sebesar -0.2412 .

Tabel 10 Kinerja Reksa Dana Metode Sharpe 2013

\begin{tabular}{|l|l|l|}
\hline INDEK PASAR & KODE & $\begin{array}{l}\text { SHARPE } \\
\mathbf{2 0 1 3}\end{array}$ \\
\hline IHSG & IHSG & -0.1041 \\
\hline LQ 45 & LQ 45 & -0.1259 \\
\hline REKSA DANA SAHAM & & \\
\hline Reksa Dana Millenium Equity & 00D61B & 0.3167 \\
\hline Grow-2-Prosper & 0086504 & 0.1712 \\
\hline
\end{tabular}




\begin{tabular}{|l|l|l|}
\hline Pratama Saham & 0099424 & 0.1114 \\
\hline Batavia Dana Saham Optimal & 0086769 & 0.0183 \\
\hline Batavia Dana Saham & BAM SAH & 0.0063 \\
\hline Rencana Cerdas & 0091017 & -0.2438 \\
\hline TRIM Kapital & 000D2B & -0.2499 \\
\hline BNI Reksadana Berkembang & 000D1B & -0.2471 \\
\hline Reksa Dana TRIM Kapital Plus & 000D2L & -0.2814 \\
\hline Batavia Dana Saham Agro & 0085001 & -0.5498 \\
\hline
\end{tabular}

Sumber: Hasil Pengolahan Data

Tabel 10 menunjukkan hasil perhitungan kinerja reksa dana, IHSG dan LQ45 menggunkan metode Sharpe untuk tahun 2013, Reksa Dana Millenium Equity memiliki kinerja paling tinggi diantara lima reksa dana yang memiliki kinerja tertinggi, yaitu sebesar 0.3167 dan mampu outperform dari IHSG sebesar -0.1041 dan LQ45 sebesar 0.1259. untuk reksa dana yang memiliki kinerja terendah masih Batavia Dana Saham Agro dengan nilai negatif sebesar -0.5498 .

\section{Penilaian Berdasarkan Metode Treynor}

Dari 29 reksa dana yang menjadi sampel penelitian penulis, dihitung kinerja reksa dana menggunakan metode Treynor, dipilihlah lima reksa dana yang memiliki nilai paling tinggi dan lima yang memiliki nilai terendah (ditandai dengan warna merah) setiap tahun dari tahun 2009 sampai 2013, berikut hasilnya:

Tabel 11 Reksa Dana Metode Treynor 2009

\begin{tabular}{|l|l|l|l|}
\hline INDEK PASAR & KODE & \multicolumn{2}{l|}{ TREYNOR 2009 } \\
\hline & & IHSG & LQ 45 \\
\hline IHSG & IHSG & 0.0544 & \\
\hline LQ 45 & LQ 45 & & 0.0541 \\
\hline REKSA DANA SAHAM & & & \\
\hline Pratama Saham & 0099424 & 0.0898 & 0.0901 \\
\hline Reksa Dana TRIM Kapital Plus & 000D2L & 0.0859 & 0.0861 \\
\hline Reksa Dana Makinta Mantap & 00D68D & 0.0785 & 0.0791 \\
\hline Panin Dana Prima & GR002PRIMASH & 0.0785 & 0.0785 \\
\hline Reksa Dana BNP Paribas Solaris & FOSL & 0.0749 & 0.0752 \\
\hline Rencana Cerdas & 0091017 & 0.0548 & 0.0548 \\
\hline Reksa Dana Millenium Equity & 00D61B & 0.0543 & 0.0543 \\
\hline Reksa Dana Makinta Growth Fund & 00D68B & 0.0520 & 0.0522 \\
\hline FS Indoequity Dividend Yield Fund & 035600048431 & 0.0517 & 0.0517 \\
\hline Reksa Dana MNC Dana Ekuitas & BIG-EQ & 0.0351 & 0.0351 \\
\hline
\end{tabular}

Sumber: Hasil Pengolahan Data

Berdasarkan tabel di atas yang menunjukkan lima kinerja reksa dana yang memiliki nilai tertinggi dan lima kinerja reksa dana terendah yang diukur menggunakan metodeTreynor, Pratama Saham memiliki kinerja yang paling tinggi sebesar 0.0898 untuk IHSG dan 0.0901 untuk LQ45, dan mampu outperform dibandingkan IHSG sebesar 0.0544 dan LQ45 sebesar 0.0541. Untuk kinerja reksa dana yang terendah 
tahun 2009 adalah Reksa Dana MNC Dana Ekuitas sebesar 0.0351 untuk IHSG dan LQ45.

Tabel 12. Reksa Dana Metode Treynor 2010

\begin{tabular}{|l|l|l|l|}
\hline INDEK PASAR & KODE & \multicolumn{2}{l|}{ TREYNOR 2010 } \\
\hline & & IHSG & LQ 45 \\
\hline IHSG & IHSG & 0.0197 & \\
\hline LQ 45 & LQ 45 & & 0.0102 \\
\hline REKSA DANA SAHAM & & & \\
\hline Reksa Dana MNC Dana Ekuitas & BIG-EQ & 0.0283 & 0.0294 \\
\hline Panin Dana Prima & GR002PRIMASH & 0.0265 & 0.0265 \\
\hline Syailendra Equity Opportunity Fund & 0085290 & 0.0202 & 0.0204 \\
\hline BNP Paribas Ekuitas & 0089763 & 0.0180 & 0.0180 \\
\hline Grow-2-Prosper & 0086504 & 0.0174 & 0.0176 \\
\hline Reksa Dana Simas Danamas Saham & $000 D 80$ & 0.0077 & 0.0079 \\
\hline Reksa Dana Makinta Mantap & $00 D 68 D$ & 0.0066 & 0.0071 \\
\hline CIMB-Principal Equity Aggressive & 0099556 & 0.0070 & 0.0069 \\
\hline First State Indoequity Value Select Fund & 0085100 & 0.0057 & 0.0056 \\
\hline Reksa Dana Millenium Equity & 00D61B & -0.0058 & -0.0053 \\
\hline
\end{tabular}

Sumber: Hasil Pengolahan Data

Tabel 12 menunjukkan hasil perhitungan kinerja reksa dana, IHSG dan LQ45 menggunakan metode Treynor untuk tahun 2010, dari lima reksa dana yang memiliki kinerja tertinggi, Reksa Dana MNC Dana Ekuitas memiliki kinerja paling tinggi sebesar 0.0283 untuk IHSG dan 0.0294 untuk LQ45 dan mampu outperform terhadap IHSG sebesar 0.0197 dan LQ45 sebesar 0.0102, sangat berbeda dengan tahun sebelumnya Reksa Dana MNC Dana Ekuitas memiliki kinerja paling rendah, perolehan Beta sangat mempengaruhi pengukuran kinerja menggunakan metode Treynor ini, untuk reksa dana yang memiliki kinerja terendah adalah Reksa Dana Millenium Equity dengan nilai negatif sebesar -0.0058 untuk IHSG dan -0.0053 untuk LQ45.

Tabel 4.13 Reksa Dana Metode Treynor 2011

\begin{tabular}{|l|l|l|l|}
\hline INDEK PASAR & KODE & \multicolumn{2}{l|}{ TREYNOR 2011 } \\
\hline & & IHSG & LQ 45 \\
\hline IHSG & IHSG & 0.0088 & \\
\hline LQ 45 & LQ 45 & & 0.0091 \\
\hline REKSA DANA SAHAM & & & \\
\hline Reksa Dana Makinta Mantap & 00D68D & 0.0348 & 0.0373 \\
\hline TRIM Kapital & 000D2B & 0.0179 & 0.0184 \\
\hline Reksa Dana TRIM Kapital Plus & 000D2L & 0.0163 & 0.0166 \\
\hline Reksa Dana Makinta Growth Fund & 00D68B & 0.0154 & 0.0165 \\
\hline Reksa Dana Schroder Dana Istimewa & 006600829471 & 0.0119 & 0.0122 \\
\hline Reksa Dana BNP Paribas Insfrastruktur Plus & FOIP & -0.0001 & -0.0001 \\
\hline Grow-2-Prosper & 0086504 & -0.0004 & -0.0004 \\
\hline Reksa Dana Simas Danamas Saham & $000 \mathrm{D} 80$ & -0.0036 & -0.0034 \\
\hline Pratama Saham & 0099424 & -0.0053 & -0.0049 \\
\hline Batavia Dana Saham Agro & 0085001 & -3.5854 & -0.2806 \\
\hline
\end{tabular}

Sumber: Hasil Pengolahan Data 
Tabel di atas menunjukkan hasil perhitungan kinerja reksa dana, IHSG dan LQ45 untuk tahun 2011. Reksa Dana Makinta Mantap memiliki kinerja paling tinggi diantara lima reksa dana yang memiliki kinerja tertinggi yaitu sebesar 0.0348 untuk IHSG dan 0.0373 untuk LQ45, dan mampu outperform terhadap IHSG sebesar 0.0088 dan LQ45 sebesar 0.0091. untuk lima reksa dana yang memiliki kinerja terendah memiliki nilai yang negatif, yang paling rendah kinerja reksa dana Batavia

Tabel 14 Reksa Dana Metode Treynor 2012

\begin{tabular}{|l|l|l|l|}
\hline INDEK PASAR & KODE & \multicolumn{2}{l|}{ TREYNOR 2012 } \\
\hline & & IHSG & LQ 45 \\
\hline IHSG & IHSG & 0.0078 & \\
\hline LQ 45 & LQ 45 & & 0.0052 \\
\hline REKSA DANA SAHAM & & & \\
\hline Batavia Dana Saham Agro & 0085001 & 0.0575 & 0.1532 \\
\hline Reksa Dana Simas Danamas Saham & $000 D 80$ & 0.0325 & 0.0561 \\
\hline Reksa Dana MNC Dana Ekuitas & BIG-EQ & 0.0176 & 0.0200 \\
\hline Syailendra Equity Opportunity Fund & 0085290 & 0.0159 & 0.0185 \\
\hline Pratama Saham & 0099424 & 0.0156 & 0.0137 \\
\hline Rencana Cerdas & 0091017 & 0.0033 & 0.0031 \\
\hline Reksa Dana Millenium Equity & $00 D 61 B$ & 0.0002 & 0.0002 \\
\hline Schroder Dana Prestasi Plus & 0090829 & -0.0008 & -0.0007 \\
\hline CIMB-Principal Equity Aggressive & 0099556 & -0.0005 & -0.0005 \\
\hline Reksa Dana NISP Indeks Saham Progresif & NISP & -0.0006 & -0.0005 \\
\hline
\end{tabular}

Sumber: Hasil Pengolahan Data

Tahun 2012 dapat kita lihat dari tabel hasil pengukuran kinerja reksa dana, IHSG dan LQ45, Batavia Dana Saham Agro memiliki kinerja paling tinggi diantara lima reksa dana yang memiliki kinerja tertinggi dengan nilai 0.0575 untuk IHSG dan 0.1532 untuk LQ45 dan mampu outperform terhadap IHSG sebesar 0.0078 dan LQ45 sebesar 0.0052, di samping itu Reksa Dana MNC Dana Ekuitas dan reksa dana Pratama Saham juga memiliki kinerja yang cukup tinggi karena termasuk pada lima kinerja reksa dana yang memiliki kinerja tertinggi dan mampu outperform terhadap IHSG dan LQ45. Untuk reksa dana yang memiliki kinerja terendah adalah Reksa Dana NISP Indeks Saham Progresif dengan perolehan nilai negatif sebesar -0.0006 untuk IHSG dan -.0005 untuk LQ45.

Tabel 15 Reksa Dana Metode Treynor 2013

\begin{tabular}{|l|l|l|l|}
\hline INDEK PASAR & KODE & \multicolumn{2}{l|}{ TREYNOR 2013 } \\
\hline & & IHSG & LQ 45 \\
\hline IHSG & IHSG & -0.0054 & \\
\hline LQ 45 & LQ 45 & & -0.0071 \\
\hline REKSA DANA SAHAM & & & \\
\hline Grow-2-Prosper & 0086504 & 0.0932 & 0.1521 \\
\hline Pratama Saham & 0099424 & 0.0103 & 0.0114 \\
\hline Batavia Dana Saham Optimal & 0086769 & 0.0011 & 0.0012 \\
\hline Batavia Dana Saham & BAM SAH & 0.0004 & 0.0004 \\
\hline Panin Dana Prima & GR002PRIMASH & 0.0001 & 0.0001 \\
\hline TRIM Kapital & 000D2B & -0.0130 & -0.0128 \\
\hline
\end{tabular}




\begin{tabular}{|l|l|l|l|}
\hline Reksa Dana Mandiri Investa Atraktif & 035600055431 & -0.0136 & -0.0136 \\
\hline Rencana Cerdas & 0091017 & -0.0143 & -0.0142 \\
\hline Batavia Dana Saham Agro & 0085001 & -0.0238 & -0.0231 \\
\hline Reksa Dana Millenium Equity & 00D61B & -5.8729 & -0.5182 \\
\hline
\end{tabular}

Sumber: Hasil Pengolahan Data

Tabel di atas dapat di lihat lima reksa dana yang memiliki kinerja tertinggi dan lima reksa dana yang memiliki kinerja terendah menggunakan metode Treynor untuk tahun 2013. Reksa dana Grow-2-Prosper memiliki kinerja yang paling tinggi dengan nilai 0.0932 untuk IHSG dan 0.11521 untuk LQ45 dan mampu outperform terhadap IHSG sebesar -0.0054 dan LQ45 sebesar -0.0071. Di samping itu reksa dana Pratama Saham dapat dikatakan memiliki kinerja yang cukup baik karena termasuk pada lima reksa dana yang memiliki kinerja tertinggi untuk tahun 2013 dan mampu outperform terhadap IHSG dan LQ45. Untuk reksa dana yang memiliki kinerja paling rendah sama dengan tahun 2009 dan 2010 adalah Reksa Dana Millenium Equity dengan nilai negatif -5.8729 untuk IHSG dan -0.5182 untuk LQ45

\section{Penilaian Berdasarkan Metode Jensen}

Dari 29 reksa dana yang menjadi sampel penelitian penulis, dihitung kinerja reksa dana menggunakan metode Jensen, dipilihlah lima reksa dana yang memiliki nilai paling tinggi dan lima yang memiliki nilai terendah (ditandai dengan warna merah) setiap tahun dari tahun 2009 sampai 2013, berikut hasilnya:

Tabel 16 Kinerja Reksa Dana Metode Jensen 2009

\begin{tabular}{|l|l|l|l|}
\hline INDEK PASAR & KODE & \multicolumn{2}{|l|}{ JENSEN 2009 } \\
\hline & & IHSG & LQ 45 \\
\hline IHSG & IHSG & 0.0091 & \\
\hline LQ 45 & LQ 45 & & 0.0095 \\
\hline REKSA DANA SAHAM & & & \\
\hline Pratama Saham & 0099424 & 0.0355 & 0.0360 \\
\hline Reksa Dana TRIM Kapital Plus & 000D2L & 0.0319 & 0.0323 \\
\hline Panin Dana Prima & GR002PRIMASH & 0.0244 & 0.0248 \\
\hline Reksa Dana Makinta Mantap & 00D68D & 0.0232 & 0.0239 \\
\hline Reksa Dana BNP Paribas Solaris & FOSL & 0.0209 & 0.0214 \\
\hline Rencana Cerdas & 0091017 & 0.0009 & 0.0012 \\
\hline Reksa Dana Millenium Equity & 00D61B & 0.0004 & 0.0007 \\
\hline Reksa Dana Makinta Growth Fund & 00D68B & -0.0019 & -0.0014 \\
\hline FS Indoequity Dividend Yield Fund & 035600048431 & -0.0022 & -0.0019 \\
\hline Reksa Dana MNC Dana Ekuitas & BIG-EQ & -0.0186 & -0.0183 \\
\hline
\end{tabular}

Sumber: Hasil Pengolahan Data

Tabel 16 menunjukkan hasil pengukuran kinerja reksa dana, IHSG dan LQ45 menggunakan metode Jensen untuk tahun 2009, reksa dana Pratama Saham memiliki kinerja yang paling tinggi dengan nilai 0.0355 untuk IHSG dan 0.0360 untuk LQ45 dan mampu outperform terhadap IHSG sebesar 0.0091 dan LQ45 0.0095, untuk reksa dana yang memiliki kinerja yang paling rendah adalah Reksa Dana MNC Dana Ekuitas dengan nilai negatif sebesar -0.0186 untuk IHSG dan -0.0183 untuk LQ45. 
Tabel 17 Dana Metode Jensen 2010

\begin{tabular}{|l|l|l|l|}
\hline INDEK PASAR & KODE & \multicolumn{2}{l|}{ JENSEN 2010 } \\
\hline & & IHSG & LQ 45 \\
\hline IHSG & IHSG & -0.0060 & \\
\hline LQ 45 & LQ 45 & & 0.0028 \\
\hline REKSA DANA SAHAM & & & \\
\hline Reksa Dana MNC Dana Ekuitas & BIG-EQ & 0.0088 & 0.0176 \\
\hline Panin Dana Prima & GR002PRIMASH & 0.0075 & 0.0166 \\
\hline Syailendra Equity Opportunity Fund & 0085290 & 0.0013 & 0.0105 \\
\hline Reksa Dana Makinta Mantap & 00 D68D & -0.0097 & -0.0019 \\
\hline Reksa Dana Simas Danamas Saham & $000 D 80$ & -0.0109 & -0.0017 \\
\hline CIMB-Principal Equity Aggressive & 0099556 & -0.0117 & -0.0028 \\
\hline First State Indoequity Value Select Fund & 0085100 & -0.0130 & -0.0041 \\
\hline Reksa Dana Millenium Equity & 00D61B & -0.0130 & -0.0087 \\
\hline
\end{tabular}

Sumber: Hasil Pengolahan Data

Tabel 4.17 menunjukkan hasil perhitungan kinerja reksa dana, IHSG dan LQ45 menggunakan metode Jensen untuk tahun 2010, Reksa Dana MNC Dana Ekuitas memiliki kinerja yang paling tinggi dengan nilai 0.0088 untuk IHSG dan 0.0176 untuk LQ45 dan mampu outperform terhadap IHSG sebesar -0.0060 dan LQ45 0.0028. Reksa dana yang memiliki kinerja yang paling rendah adalah Reksa Dana Millenium Equity dengan nilai negatif -0.0130 untuk IHSG dan -0.0087 untuk LQ45.

Tabel 18 Reksa Dana Metode Jensen 2011

\begin{tabular}{|l|l|l|l|}
\hline INDEK PASAR & KODE & \multicolumn{2}{l|}{ JENSEN 2011 } \\
\hline & & IHSG & LQ 45 \\
\hline IHSG & IHSG & -0.0005 & \\
\hline LQ 45 & LQ 45 & & -0.0007 \\
\hline REKSA DANA SAHAM & & & \\
\hline Reksa Dana Makinta Mantap & 00D68D & 0.0215 & 0.0216 \\
\hline TRIM Kapital & 000D2B & 0.0092 & 0.0092 \\
\hline Reksa Dana TRIM Kapital Plus & 000D2L & 0.0084 & 0.0083 \\
\hline Reksa Dana Makinta Growth Fund & 00D68B & 0.0065 & 0.0067 \\
\hline Reksa Dana Schroder Dana Istimewa & 006600829471 & 0.0041 & 0.0040 \\
\hline Grow-2-Prosper & 0086504 & -0.0071 & -0.0074 \\
\hline Reksa Dana Simas Danamas Saham & 000D80 & -0.0067 & -0.0071 \\
\hline $\begin{array}{l}\text { Reksa Dana BNP Paribas Insfrastruktur } \\
\text { Plus }\end{array}$ & F0IP & -0.0058 & -0.0063 \\
\hline Pratama Saham & 0099424 & -0.0071 & -0.0075 \\
\hline Batavia Dana Saham Agro & 0085001 & -0.0203 & -0.0209 \\
\hline
\end{tabular}

Sumber: Hasil Pengolahan Data

Tabel di atas menunjukkan lima reksa dana yang memiliki kinerja yang paling tinggi dan lima reksa dana yang memiliki kinerja yang paling rendah, Reksa Dana Makinta Mantap memiliki kinerja yang paling tinggi sebesar 0.0215 untuk IHSG dan 0.0216 untuk LQ45, serta mampu outperform terhadap IHSG sebesar -0.0005 dan LQ45 0.0007 , untuk reksa dana yang memiliki kinerja yang paling rendah adalah reksa dana 
Batavia Dana Saham Agro dengan nilai yang negatif -0.0203 untuk IHSG dan LQ45 0.0209 .

Tabel 19 Reksa Dana Metode Jensen 2012

\begin{tabular}{|l|l|l|l|}
\hline INDEK PASAR & KODE & \multicolumn{2}{|l|}{ JENSEN 2012 } \\
\hline & & IHSG & LQ 45 \\
\hline IHSG & IHSG & -0.0005 & \\
\hline LQ 45 & LQ 45 & & 0.0011 \\
\hline REKSA DANA SAHAM & & & \\
\hline Reksa Dana MNC Dana Ekuitas & BIG-EQ & 0.0108 & 0.0131 \\
\hline Syailendra Equity Opportunity Fund & 0085290 & 0.0088 & 0.0112 \\
\hline Reksa Dana BNP Paribas Solaris & FOSL & 0.0046 & 0.0069 \\
\hline Reksa Dana TRIM Kapital Plus & 000D2L & 0.0038 & 0.0059 \\
\hline Reksa Dana Makinta Mantap & 00D68D & 0.0038 & 0.0052 \\
\hline Reksa Dana Millenium Equity & 00D61B & -0.0053 & -0.0035 \\
\hline Reksa Dana NISP Indeks Saham Progresif & NISP & -0.0051 & -0.0040 \\
\hline CIMB-Principal Equity Aggressive & 0099556 & -0.0052 & -0.0038 \\
\hline Reksa Dana Simas Danamas Saham & 000D80 & -0.0077 & -0.0088 \\
\hline Batavia Dana Saham Agro & 0085001 & -0.0132 & -0.0144 \\
\hline
\end{tabular}

Sumber: Hasil Pengolahan Data

Tabel di atas menunjukkan kinerja reksa dana yang memiliki kinerja yang tertinggi menggunakan metode Jensen untuk tahun 2012. Reksa Dana MNC Dana Ekuitas memiliki kinerja yang paling tinggi dengan nilai 0.0108 untuk IHSG dan 0.0131 untuk LQ45, serta mampu outperform terhadap IHSG sebesar -0.005 dan LQ45 0.0011, di samping itu Reksa Dana TRIM Kapital Plus dan Reksa Dana Makinta Mantap juga dapat dikatakan memiliki kinerja yang cukup baik karena memiliki kinerja yang termasuk pada lima tertinggi untuk tahun 2012. Untuk reksa dana yang memiliki kinerja yang paling rendah adalah Batavia Dana Saham Agro dengan nilai negatif 0.0132 untuk IHSG dan LQ45 sebesar -0.0144.

Tabel 20 Reksa Dana Metode Jensen 2013

\begin{tabular}{|l|l|l|l|}
\hline INDEK PASAR & KODE & \multicolumn{3}{l|}{ JENSEN 2013} \\
\hline & & IHSG & LQ 45 \\
\hline IHSG & IHSG & -0.0005 & \\
\hline LQ 45 & LQ 45 & & 0.0006 \\
\hline REKSA DANA SAHAM & & & \\
\hline Reksa Dana Millenium Equity & $00 \mathrm{D} 61 \mathrm{~B}$ & 0.0453 & 0.0448 \\
\hline Pratama Saham & 0099424 & 0.0136 & 0.0143 \\
\hline Grow-2-Prosper & 0086504 & 0.0085 & 0.0084 \\
\hline Batavia Dana Saham Optimal & 0086769 & 0.0057 & 0.0067 \\
\hline Batavia Dana Saham & BAM SAH & 0.0050 & 0.0060 \\
\hline Rencana Cerdas & 0091017 & -0.0090 & -0.0076 \\
\hline Reksa Dana Mandiri Investa Atraktif & 035600055431 & -0.0084 & -0.0071 \\
\hline Reksa Dana TRIM Kapital Plus & $000 \mathrm{D} 2 \mathrm{~L}$ & -0.0117 & -0.0102 \\
\hline BNI Reksadana Berkembang & $000 \mathrm{D} 1 \mathrm{~B}$ & -0.0119 & -0.0105 \\
\hline Batavia Dana Saham Agro & 0085001 & -0.0171 & -0.0157 \\
\hline
\end{tabular}

Sumber: Hasil Pengolahan Data 
Tabel di atas menunjukkan kinerja reksa dana, IHSG dan LQ45 dengan menggunakan Jensen untuk tahun 2013, Reksa Dana Mallenium Equity memiliki kinerja yang paling tinggi dengan nilai sebesar 0.0453 untuk IHSG dan 0.0448 untuk LQ45, reksa dana Batavia Dana Saham Agro memiliki kinerja yang paling rendah dengan nilai negatif -0.0171 untuk IHSG dan -0.0157 untuk LQ45.

\section{Perbedaan Pengukuran Kinerja Reksa Dana Menggunakan Metode Sharpe,} Treynor Dan Jensen

Tabel 4.21 Perbedaan Pengukuran Menggunakan Metode Sharpe, Treynor Dan Jensen

\begin{tabular}{|l|l|l|l|l|l|l|}
\hline \multirow{2}{*}{ REKSA DANA SAHAM } & EXPECTED & \multirow{2}{*}{ RETURN } & \multirow{2}{*}{ SHARPE } & \multicolumn{2}{l|}{ TREYNOR } & \multicolumn{2}{l|}{ JENSEN } \\
\cline { 4 - 8 } & & & IHSG & LQ 45 & IHSG & LQ 45 \\
\hline IHSG & 0.0217 & 0.2649 & 0.0170 & - & 0.0003 & - \\
\hline LQ 45 & 0.0192 & 0.2018 & - & 0.0143 & - & 0.0027 \\
\hline AVERAGE REKSA DANA & 0.0214 & 0.1958 & -0.0476 & 0.0135 & 0.0003 & 0.0027 \\
\hline
\end{tabular}

Sumber: Hasil Pengolahan Data

Dari tabel 21 dapat dilihat hasil pengukuran kinerja menggunakan metode Sharpe, Treynor dan Jensen. Rata-rata reksa dana belum mampu outperform terhadap IHSG dan LQ45, baik dilihat dari expected return, pengukuran kinerja menggunakan metode Sharpe, Treynor dan Jensen. Dari ketiga pengukuran kinerja menggunakan metode Sharpe, Treynor dan Jensen menunjukkan hasil yang tidak jauh berbeda pula, bahwa rata-rata reksa dana belum mampu memiliki kinerja yang lebih baik dibanding kinerja IHSG dan LQ45.

\section{Gambar 1. Grafik Rata-rata Hasil Pengukuran Kinerja Menggunakan Ketiga Metode}

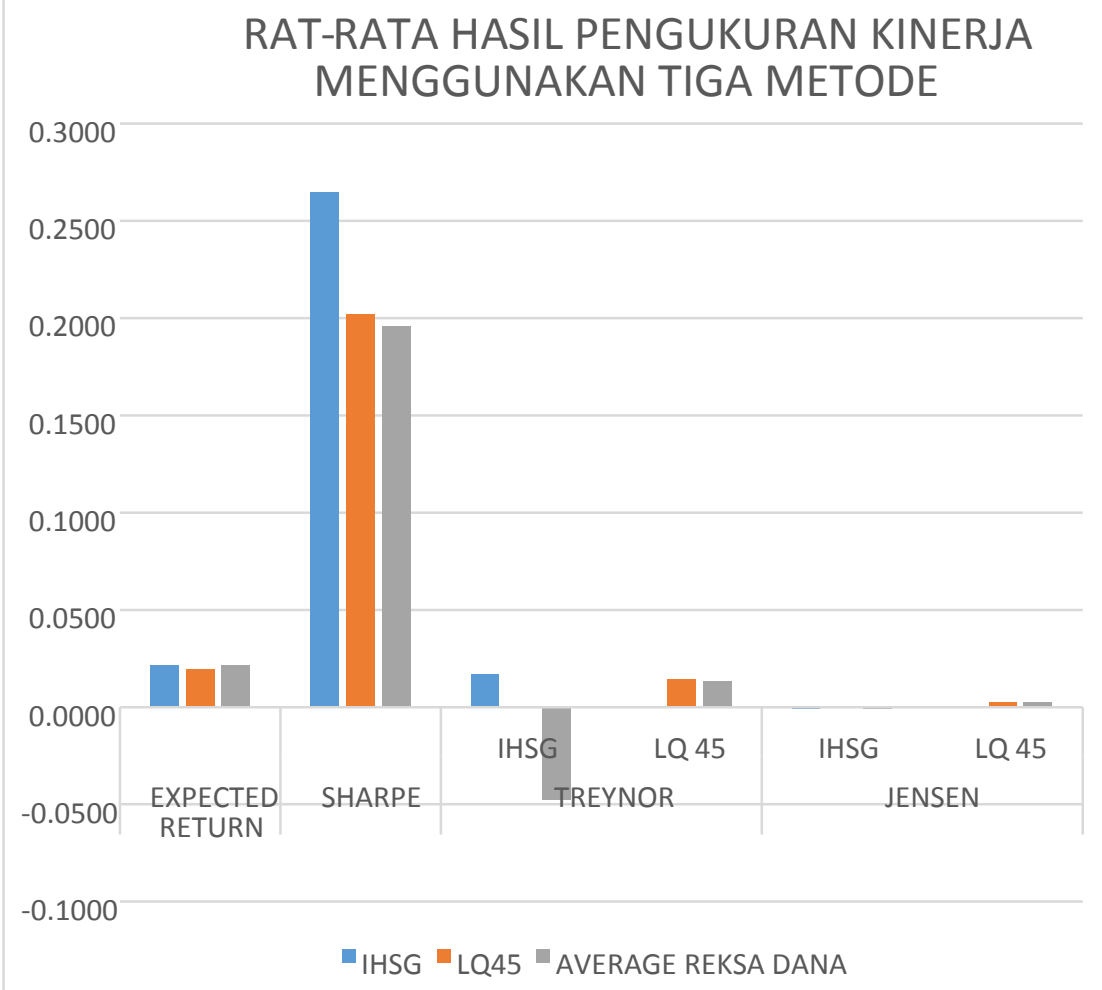


Dari grafik dapat dilihat rata-rat hasil pengukuran kinerja reksa dana menggunakan metode Sharpe, Treynor dan Jensen, dengan menunjukkan hasil bahwa tidak terdapat perbedaan yang signifikan pengukuran kinerja menggunakan metode Sharpe, Treynor dan Jensen, rata-rat kinerja reksa dana belum mampu lebih baik dari kinerja IHSG dan LQ45.

\section{Penilaian Kinerja Reksa Dana Saham Periode 2009 Sampai 2013}

Pada tahun 2009 sampai 2012

1. berdasarkan expected return, rata-rata semua produk reksa dana saham memperoleh expected return yang positif. Hal ini menunjukkan bahwa produk reksa dana tersebut mampu memberikan keuntungan untuk para pemilik reksa dana yang berinvestasi di dalamnya. Sedangkan pada tahun 2013 rata-rata produk reksa dana memperoleh hasil yang negatif. Hal ini menunjukkan bahwa reksa dana tersebut mengalami kerugian sehingga tidak mampu memberikan keuntungan bagi para pemilik reksa dana. Penilaian kinerja reksa dana yang paling baik dan mampu outperform terhadap indek pasar IHSG dan LQ45 tahun 2009 sampai 2013.

2. Berdasarkan metode Sharpe, Treynor dan Jensen terdapat beberapa kinerja reksa dana yang paling baik dibandingkan kinerja pasar IHSG dan LQ45 dan mampu outperform. Berdasarkan metode Sharpe kinerja Reksa Dana MNC Dana Ekuitas memiliki kinerja paling baik dan mampu outperform dibandingkan dengan kinerja pasar IHSG dan LQ45 dan mampu bertahan selama tiga tahun, yaitu tahun 2009, 2010 dan 2012. Berdasarkan metode Treynor, Pratama Saham mampu memberikan kinerja paling baik dan mampu outperform dibandingkan pasar IHSG dan LQ45, bertahan selama tiga tahun, yaitu tahun 2009, 2012 dan 2013, di samping itu walaupun tidak memiliki kinerja yang cukup baik, Reksa Dana MNC Dana Ekuitas tetap mampu outperform terhadap pasar IHSG dan LQ45. Sedangkan berdasarkan metode Jensen Reksa Dana Trim Kapital Plus yang mampu memberikan kinerja paling baik terhadap pasar IHSG dan LQ45 yang mampu bertahan selama tiga tahun 2009, 2012 dan 2013. Dan Reksa Rana MNC Dana Ekuitas tetap mampu outperform terhadap pasar IHSG dan LQ45, walaupun tidak memiliki kinerja yang cukup baik dibandingkan Reksa Dana Trim Kapital Plus.

3. Secara keseluruhan hanya terdapat beberapa reksa dana yang mampu memiliki kinerja lebih baik dan mampu outperform dibandingkan kinerja pasar IHSG dan LQ45, namun tidak dapat bertahan lama untuk periode tertentu. Jadi pasar IHSG dan LQ45 memiliki kinerja yang lebih baik jika dibandingkan dengan kinerja reksa dana. Bedasarkan hasil yang diperoleh penelitian ini medukung penelitian wahdah dan hartanto, 2012 yang menunjukkan hanya beberapa reksa dana yang memiliki kinerja di atas kinerja pasar diukur menggunakan metode Sharpe, Treynor dan Jensen.

\section{KESIMPULAN}

Dari hasil yang diperoleh dari tidak adanya perbedaan yang bermakna terhadap pengukuran kinerja portofolio menggunakan metode Sharpe, Treynor dan Jensen, maka dalam hal ini pemilihan pengukuran kinerja portofolio akan dikembalikan kembali kepada investor atau pelaku pasar modal. Jika investor lebih menekan pada beta portofolio sebagai bahan pertimbangan utama maka penggunaan metode Treynor mungkin akan menghasilkan ukuran kinerja yang lebih baik. 
Namun jika investor menekankan pada resiko return portofolio maka penggunaan kinerja Sharpe yang menggunakan standar deviasi portofolio mungkin akan menghasilkan pengukuran yang lebih baik. Demikian pula jika investor mempertimbangkan selisih premi risiko portofolio dengan premi risiko pasar ukuran kinerja dengan metode Jensen akan merupakan metode yang paling tepat.

\section{SARAN}

Sebagai harapan akan dilakukannya analisis lebih lanjut dengah hasil yang lebih baik, maka beberapa saran sebagai berikut:

1. Perhitungan kinerja portofolio dapat digunakan untuk menghitung reksa dana pendapatan tetap, reksa dana pasar uang dan reksa dana campuran, namun harus diperhatikan pembandingnya (benchmark) yang tepat dan sesuai.

2. Analisis kinerja portofolio dapat menggunakan data harian dalam perhitungan return portofolio untuk mendapatkan hasil yang lebih akurat.

\section{DAFTAR REFERENSI}

Dewi, Miranti Kartika dan Ilham Reza Ferdian. (2006). Evaluating Performance of Islamic Mutual Funds in Indonesia and Malaysia. Centre for Islamic Economics and Business Department of Accounting- Faculty of Economics, University of Indonesia, Indonesia.

http://aria.bapepam.go.id/reksadana/statistik.asp?page=statistik-nab-rd (informasi nilai aktiva bersih reksa dana) diakses September 2014

http://liputankhususfinansialdaninvestasi/html. (informasi mengenai penurunan IHSG selama tahun 2013)

diakses September 2015

Mariani, Ani. (2007).Analisis Kinerja Reksa Dana Syariah Dengan Metode Sharpe, Treynor, Dan Jensen. Fakultas Ekonomi Jurusan Akuntansi. Universitas

Gunadarma. (Skripsi)

Pratomo, Eko Priyo dan Ubaidillah Nugraha. (2002). Reksa Dana: Solusi Perencanaan Investasi di Era Modern. Jakarta: PT. Gramedia Pustaka Utama.

(2005). Reksa Dana: Solusi Perencanaan Investasi di Era Modern. Jakarta: PT. Gramedia Pustaka Utama.

Prof. Prajapati, Kalpesh P dan Prof. Mahesh K Patel. (2012). Comparative Study On

Performance Evaluation Of Mutual Fund Schemes Of Indian Companies. Assistant Professor, S.V Institute of Management, Gujarat Technological University, Ahmedabd, Gujarat, India.

Rahardi, Aditya Nugroho. (2013). Analisis Komparasi Pengukuran Kinerja Reksa Dana Menggunakan Metode Sharpe, Treynor Dan M2 (Studi Pada Reksa Dana Saham Periode 2009-2011). Fakultas Ekonomika Dan Bisnis. Universitas Diponegoro. Semarang. (Skripsi)

Sulistyorini, Agustin. (2009). Analisis Kinerja Portofolio Saham Dengan Metode Sharpe, Treynor Dan Jensen. Program Pasca Sarjana. Universitas Diponegoro. Semarang. (Tesis)

Susiana, Yosefa dan Arnold Kaudin, (2009). Evaluasi Kinerja Reksa Dana Saham Di Indonesia Tahun 2006. Fakultas Ekoomika Dan Bisnis. Universitas Kristen Surya Wacana. Salatiga. 
Tandelilin, Eduardus. (2001). Analisis Investasi dan Manajemen Portofolio, BPFE, Yogyakarta.

Undang-undang Republik Indonesia. (1995). Undang-undang Pasar Modal No.8 Tahun 1995 tentang Reksa Dana. Jakarta.

http://hukumpidana.bphn.go.id/kuhpoutuu/undang-undang-nomor-8-tahun1995tentang-pasar-modal/ diakses 08 November 2014

Wahdah, Rofiqah dan Joko Hartanto, (2012). Analisis Pengukuran Kinerja Reksa

Dana Saham Di Indonesia. Program Studi Manajemen Sekolah Tinggi Ilmu Ekonomi Indonesia. Banjarmasin.

Winigrum, Evi Putri. (2011). Analisis Stock Selection Skills, Market Timing Ability, Size Reksa Dana, Umur Reksa Dana Dan Expense Ratio Terhadap Kinerja Reksa Dana Saham Yang Terdaftar Di Bursa Efek Indonesia Periode Tahun 20062010. Fakultas Ekonomi Universitas Diponegoro. Semarang. (Skripsi).

www.bi.go.id (informasi suku bunga bank indonesia) diakses Maret 2015

www.duniainvestasi.com/bei/prices/stock (informasi indeks price IHSG dan LQ45) diakses Maret 2015

www.idx.co.id/id-id/beranda/informasipasar/daftarefek/indekskonstituen.aspx (informasi reksa dana) diakses Maret 2015 